bioRxiv preprint doi: https://doi.org/10.1101/2022.03.07.483228; this version posted March 7, 2022. The copyright holder for this preprint (which was not certified by peer review) is the author/funder, who has granted bioRxiv a license to display the preprint in perpetuity. It is made available under aCC-BY 4.0 International license.

\title{
1 Cell-cell metabolite exchange creates a pro-survival metabolic environment that \\ 2 extends lifespan
}

3

4 Clara Correia-Melo ${ }^{\# 1,2,3}$, Stephan Kamrad ${ }^{1}$, Christoph B. Messner ${ }^{1}$, Roland Tengölics ${ }^{4,5}$, Lucía

5 Herrera-Dominguez ${ }^{1,3}$, St John Townsend ${ }^{1,3}$, Mohammad Tauqeer Alam ${ }^{6}$, Anja Freiwald ${ }^{7}$, Kate

6 Campbell ${ }^{2}$, Simran Aulakh¹, Lukasz Szyrwiel ${ }^{1,3}$, Jason S. L. Yu1', Aleksej Zelezniak ${ }^{1,8,19,10}$, Vadim

7 Demichev ${ }^{1,2,3}$, Michael Muelleder ${ }^{7}$, Balázs Papp ${ }^{4,5}$, and Markus Ralser ${ }^{\# 1,3}$

8

9 \# Corresponding authors CC-M (clara.correia-melo@charite.de) \& MR (markus.ralser@charite.de)

$11{ }^{1}$ The Molecular Biology of Metabolism Laboratory, The Francis Crick Institute, London, UK

$12{ }^{2}$ Department of Biochemistry, University of Cambridge, Cambridge, UK

$13{ }^{3}$ Department of Biochemistry, Charité University Medicine, Berlin, Germany

$14{ }^{4}$ Synthetic and Systems Biology Unit, Institute of Biochemistry, Biological Research Centre, Eötvös

15 Loránd Research Network; Szeged, Hungary

$16{ }^{5}$ HCEMM-BRC Metabolic Systems Biology Lab; Szeged, Hungary

$17{ }^{6}$ Department of Biology, College of Science, United Arab Emirates University, Al-Ain, UAE

$18{ }^{7}$ Core Facility - High Throughput Mass Spectrometry, Charité University Medicine, Berlin, Germany

$19{ }^{8}$ Department of Biology and Biological Engineering, Chalmers University of Technology, Kemivägen 10, 20 SE-412 96, Gothenburg, Sweden

$21 \quad{ }^{9}$ Science for Life Laboratory, Tomtebodavägen 23a, SE-171 65, Stockholm, Sweden

$22{ }^{10}$ Institute of Biotechnology, Life Sciences Center, Vilnius University, Vilnius, Lithuania

23 


\section{Abstract}

30

31 Metabolism is fundamentally intertwined with the ageing process. We here report that a key determinant of cellular lifespan is not only nutrient supply and intracellular metabolism, but also metabolite exchange interactions that occur between cells. Studying chronological ageing in yeast, we observed that metabolites exported by young, exponentially growing, cells are reimported during the stationary phase when cells age chronologically, indicating the existence of cross-generational metabolic interactions. We then used self-establishing metabolically cooperating communities (SeMeCos) to boost cell-cell metabolic interactions and observed a significant lifespan extension. A search for the underlying mechanisms, coupling SeMeCos, metabolic profiling, proteomics and genome-scale metabolic modelling, attributed a specific role to methionine consumer cells. These cells were enriched over time, adopted glycolytic metabolism and increased export of protective metabolites. Glycerol, in particular, accumulated in the communal metabolic environment and extended the lifespan of all cells in the community in a paracrine fashion. Our results hence establish metabolite exchange interactions as a determinant of the ageing process and show that metabolically cooperating cells shape their metabolic environment to achieve lifespan extension.

Keywords: Metabolite exchange interactions, yeast chronological ageing, self-generated

51 longevity. 


\section{Introduction}

55

56 Metabolism is interlinked with the ageing process and determines lifespan at multiple levels.

57 Processes driven or dependent on metabolism include cellular growth, ageing and death, 58 energy production and the formation of molecular building blocks required for cellular 59 homeostasis and repair, and even regulation of antimicrobial responses ${ }^{1-6}$. Moreover, metabolic sensing and metabolic signalling systems that regulate cell growth and energy expenditure, such as the AMPK, Sirtuin and mTOR pathways, are also central pathways regulating cellular ageing and lifespan ${ }^{7-11}$. Indeed, metabolism is a source of both damaging and protective molecules, and hence strongly intertwined with ageing processes. For example, metabolites like NADPH and glutathione fuel the metabolic antioxidant machinery and protect cells from oxidative damage that occurs during cellular ageing ${ }^{12}$. On the other end of the spectrum, reactive products of metabolism such as methylglyoxal or superoxide, indiscriminately react and damage cellular membranes, proteins and nucleic acids, accelerating cellular ageing phenotypes ${ }^{13-15}$. As a consequence, metabolic activity that determines the equilibrium between the levels of protective and damaging reactive molecules inside a cell is a critical determinant of ageing and lifespan ${ }^{16,17}$.

71 Cellular metabolism not only occurs inside cells, it also involves the exchange of metabolites 72 between cells and tissues ${ }^{18-22}$. In microbes, metabolite exchange interactions are a result of 73 cells exporting metabolites into their surrounding and re-importing metabolites produced by 74 themselves or neighbouring cells. Metabolite exchange interactions can be costly for cells, 75 because the exported metabolites can be lost to competitors or diffusion ${ }^{23}$, but are critical for 76 cell growth and emerge for at least three reasons. First, the ability to uptake and exploit 77 metabolites that are available environmentally renders cells more competitive. This means cells 78 profit from possessing metabolite uptake systems even in situations where there are no 79 advantages to be gained from cell-cell cooperation ${ }^{21,24}$. Second, cells export metabolites for 
bioRxiv preprint doi: https://doi.org/10.1101/2022.03.07.483228; this version posted March 7, 2022. The copyright holder for this preprint available under aCC-BY 4.0 International license.

80 many different reasons. For instance, the intracellular biochemical network needs constant

81 balancing which is achieved through an overflow of metabolites ${ }^{20,25-27}$. The export of metabolites

82 also mediates metabolic cooperation, a situation that can arise when unrelated biochemical

83 reactions interfere and inhibit each other, and where smaller metabolic networks are more

84 efficient ${ }^{28}$. Finally, the biosynthetic burden caused by expensive metabolic reactions can be

85 mitigated through the sharing of labour. This helps cells to reduce energetic costs as well as the

86 load of toxic intermediates ${ }^{21,29,30}$.

87 Intercellular metabolic interactions hence emerge because cells constantly export a broad range

88 of metabolites and, at the same time, harbour an array of mechanisms which sense and uptake

89 extracellular nutrients ${ }^{20,31-33}$. This situation has, however, a significant impact on cellular

90 physiology. Once a cell has started to uptake extracellular metabolites, its own biosynthetic

91 pathways typically become inhibited ${ }^{32,34}$. As a consequence, metabolic and physiological

92 properties that also impact ageing, such as growth rate, stress tolerance, or the formation or

93 consumption of metabolites such as $\mathrm{NADPH}$, are altered depending on the uptake of

94 metabolites ${ }^{32,35-38}$. For example, cells that uptake lysine from the environment mount better

95 protection against oxidants, via increased pools of $\mathrm{NADPH}^{37}$, and cells that rely on the uptake

96 of amino acids, including histidine, leucine, and methionine, are more drug tolerant ${ }^{38}$.

97 While there is an increasing understanding of the role of the metabolic environment in stress

98 resilience and growth, the role of cell-cell metabolic interactions in the ageing process is still

99 barely understood ${ }^{2}$. A measure of eukaryotic cell ageing is chronological lifespan (CLS) in

100 yeast. CLS refers to post-mitotic cell ageing, assessed by the length of time quiescent (non-

101 dividing) cells can survive post entry into the stationary phase ${ }^{39,40}$. CLS has been pivotal in the

102 discovery of several of the most critical and conserved regulatory pathways of ageing that are

103 now known to be important across eukaryotes, including the AMPK, mTOR and sirtuin pathways

$104^{8-11}$. Monitoring metabolic consumption and production during CLS using metabolomics and

105 isotope tracing experiments, we observe that metabolites exported by young, exponentially

106 growing, cells are re-imported during the stationary phase when cells age chronologically, 
bioRxiv preprint doi: https://doi.org/10.1101/2022.03.07.483228; this version posted March 7, 2022. The copyright holder for this preprint

(which was not certified by peer review) is the author/funder, who has granted bioRxiv a license to display the preprint in perpetuity. It is made available under aCC-BY 4.0 International license.

107 indicating the existence of cross-generational metabolic interactions. As this result implied that

108 metabolite exchange interactions could be impact CLS, we boosted metabolite export and

109 metabolic interactions through the use of self-establishing metabolically cooperating (SeMeCo)

110 communities, a yeast community model that allows the tracing of metabolite consumer or

111 producer cells of four different metabolic pathways in their sixteen possible combinations

112 (metabotypes) ${ }^{41}$. We observed a significant extension of the yeast chronological lifespan when

113 cell-cell metabolic interactions are boosted. In the search for the underlying mechanisms, we

114 coupled lifespan assays with proteomics, metabolomics and genome-scale metabolic flux

115 analysis, and discovered a role for the extracellular metabolic environment that is created by the

116 cooperating communities. We find that cells cooperating for the biosynthesis of methionine

117 generate a protective metabolic environment, in which methionine consumers obtain a more

118 glycolytic metabolism and overflow glycolytic products, glycerol in particular. The

119 exometabolome created this way, in turn, extends the lifespan of all cells in the community via a

120 paracrine effect. Our results show that widespread metabolome changes, occurring when cells

121 cooperate metabolically, create a pro-survival metabolic environment leading to extension of

122 their own lifespan. Ultimately, these findings establish cell-cell metabolic interactions and

123 generated exometabolomes as a longevity modulating mechanism.

124

125

126 Results

127

128

Yeast cells establish cross-generational metabolite exchange interactions during

chronologic ageing

130

131 As cells sense extracellular metabolites and feedback inhibit their own metabolite synthesis

132 pathways when grown in rich media ${ }^{25,31,34,41}$, we conducted CLS experiments using synthetic

133 minimal (SM) growth media lacking amino acid and nucleotide supplements. We used a 
bioRxiv preprint doi: https://doi.org/10.1101/2022.03.07.483228; this version posted March 7, 2022. The copyright holder for this preprint

(which was not certified by peer review) is the author/funder, who has granted bioRxiv a license to display the preprint in perpetuity. It is made available under aCC-BY 4.0 International license.

134 common lab strain in which four artificially introduced metabolic biosynthetic deficiencies

135 (auxotrophies) in three amino acids (his $3 \Delta 1$, leu2 $\Delta$, met15 $\Delta$ ) and one nucleobase (ura3 $\Delta)^{42}$

136 were repaired through genomic integration of the wild-type alleles ${ }^{38}$.

137 The prototrophic cells, metabolically competent for the biosynthesis of the four metabolites

138 (wild-type cells) were grown in batch culture through exponential, early stationary and stationary

139 phases (1, 2 and 8 days of culture respectively) (Fig 1a). Initially, cells grow exponentially (E),

140 consuming glucose supplemented to the culture media, followed by a decline in growth rate as

141 cells transition from diauxic shift to stationary phase (early stationary phase, ES), and then enter

142 stationary phase (S) once preferred carbon sources are exhausted. While exponential cells are

143 mostly glycolytic, they then start consuming released products of glucose catabolism (like

144 ethanol or glycerol) during the diauxic shift, before entering stationary phase, when cells arrest

145 growth and mostly use oxidative phosphorylation to generate ATP (Fig. 1a). In order to evaluate

146 the intracellular metabolome of chronologically ageing prototrophic cells, we used a targeted

147 LC-MS/MS method ${ }^{43}$. The concentration profile of intracellular amino acids, nucleotides as well

148 as glycolysis and tricarboxylic acid (TCA) intermediates was specific to the growth phase; the

149 profiles clustered in a principal component analysis (PCA) according to growth phase (Fig. 1b

150 i)). The metabolite concentration changes measured reflected the known metabolic transitions

151 from exponential to the stationary phase ${ }^{44-46}$. Consistent with a shift from fermentation to

152 oxidative metabolism, the overall concentration of glycolytic metabolites decreased, while we

153 detected an increase in the concentration of TCA derived metabolites (Fig. 1b ii)). Moreover,

154 reflecting the ceasing of growth, the concentration of nucleotides decreased during early

155 stationary and stationary phases ${ }^{46}$. Interestingly, a differentiated picture was obtained for

156 intracellular amino acids. While the concentration of overall amino acids did increase in the

157 stationary phase, we observed a spread in the concentration range (Fig. 1b ii)), unpaired two-

158 sided Wilcoxon Rank Sum test and multiple testing correction using the Benjamini \& Hochberg

$159(\mathrm{BH})$ method, adjusted p-values in Supplementary File 1). For example, isoleucine, glycine and

leucine increased from exponential to stationary phase, but aspartate, alanine and glutamate 
bioRxiv preprint doi: https://doi.org/10.1101/2022.03.07.483228; this version posted March 7, 2022. The copyright holder for this preprint

(which was not certified by peer review) is the author/funder, who has granted bioRxiv a license to display the preprint in perpetuity. It is made available under aCC-BY 4.0 International license.

161 decreased, most likely reflecting their role in interconversion reactions in the biosynthesis of

162 other metabolites, including other amino acids and pyruvate (Fig. 1c), unpaired two-sided

163 Wilcoxon Rank Sum test and multiple testing correction using the $\mathrm{BH}$ method, adjusted p-values

164 in Supplementary File 2).

165 As amino acids can be exported by yeast cells into the surrounding environment ${ }^{25,41,47-49}$, we 166 therefore continued our analysis with a quantification of the extracellular amino acid pools using 167 a targeted LC-MS/MS method ${ }^{50}$. Despite having inoculated our cells in a minimal medium 168 lacking amino acid supplements, we found that by mid-log phase (exponential phase) yeast cells had produced and exported amino acids to reach significant concentrations in the medium.

170 Further, 14 of the 19 analysed amino acids are increased by more than $>10 \%$ in the 171 extracellular medium in the stationary compared to the exponential phase medium (Fig. 1c 172 inlet). Indeed, only glutamate and aspartate were reduced in the extracellular metabolome of 173 stationary cells when compared to the medium formed by exponential cells (Fig. 1c, unpaired 174 two-sided Wilcoxon Rank sum test and multiple testing correction with BH method, adjusted p175 values in Supplementary File 2). The source of these metabolites can be metabolite export as 176 well as cell death in the stationary phase. As most of the metabolites were already increasingly 177 detected in the exponential and early stationary phases where cell death is negligible ( 95\% live 178 cells) (Supplementary Fig. 2a) and also because in stationary cultures, the concentration of 179 metabolites did not correlate with the number of live cells (Supplementary Fig. 2b), we 180 concluded that the main source of metabolites is export during the exponential and early 181 stationary phases.

182 Amino acids are sensed and efficiently uptaken by actively growing yeast cells ${ }^{25,31,47}$. We 183 therefore asked if cells during the stationary phase, no longer actively proliferating, would 184 uptake the amino acids previously produced in the exponential phase (Fig. 1d). We exploited $185{ }^{13} \mathrm{C}$-glucose isotope labelling to test for the consumption, by stationary cells, of metabolites that 186 had been produced during the exponential phase. We cultured wild-type yeast cells on SM media supplemented with ${ }^{12} \mathrm{C}$-glucose or ${ }^{13} \mathrm{C}$-glucose for $48 \mathrm{~h}$, a duration which ensured that the 
bioRxiv preprint doi: https://doi.org/10.1101/2022.03.07.483228; this version posted March 7, 2022. The copyright holder for this preprint (which was not certified by peer review) is the author/funder, who has granted bioRxiv a license to display the preprint in perpetuity. It is made available under aCC-BY 4.0 International license.

188 glucose in the media had been exhausted - catabolized into unlabeled $\left({ }^{12} \mathrm{C}\right)$ and labelled $\left({ }^{13} \mathrm{C}\right)$

189 metabolites, respectively. Then we swapped the media between labelled and unlabelled cells. In

190 parallel, we set control cultures growing on SM media supplemented with ${ }^{13} \mathrm{C}$-glucose, which

191 were then swapped into SM media only supplemented with amino acids (without glucose), to

192 allow distinguishing if intracellular amino acid levels were a direct result of import, or indirectly

193 derived from catabolism of imported carbohydrates. Levels of fully labelled $\left({ }^{13} \mathrm{C}\right)$ or unlabeled

$194\left({ }^{12} \mathrm{C}\right)$ intracellular amino acids (from glucose catabolism) were quantified using a targeted LC-

MS/MS method ${ }^{50}$ (Fig. 1e i)). Growth on SM media supplemented with ${ }^{12} \mathrm{C}$-glucose or ${ }^{13} \mathrm{C}$ -

glucose did not change cell growth parameters prior or post swap (Supplementary Fig. 3a-b,

unpaired two-sided Wilcoxon Rank sum test; p-values are listed in Supplementary File 3).

Notably, cells in exponential phase synthesise sufficient amounts of amino acids so that they

can be exported and then uptaken by neighbouring cells, as shown by the increased

intracellular levels of ${ }^{13} \mathrm{C}$ - or ${ }^{12} \mathrm{C}$-containing amino acids in cultures initially grown on ${ }^{12} \mathrm{C}$ - or ${ }^{13} \mathrm{C}$ -

glucose, respectively, or when unlabeled amino acids were added to cells previously cultured in

${ }^{13} \mathrm{C}$-glucose in the control cultures (Fig. 1e ii), Supplementary Fig. 3c). Hence amino acids that

are produced and exported during the exponential growth phase are taken up by yeast cells

during the stationary phase, indicating that yeast cells establish cross-generational metabolite exchange interactions during chronological ageing.

206

207

Metabolite exchange interactions extend lifespan in yeast communities

209

210 We next questioned what impact the exchange of metabolites might have on chronological

211 lifespan. The export and import of metabolites cannot be prevented without imposing major

212 metabolic constraints on cells. We overcame this issue by choosing to boost metabolite

213 exchange interactions instead and made use of self-establishing metabolically cooperating communities (SeMeCos) ${ }^{41}$. SeMeCos exploit the segregation of plasmids that encode for 
bioRxiv preprint doi: https://doi.org/10.1101/2022.03.07.483228; this version posted March 7, 2022. The copyright holder for this preprint

(which was not certified by peer review) is the author/funder, who has granted bioRxiv a license to display the preprint in perpetuity. It is made available under aCC-BY 4.0 International license.

215 essential metabolic enzymes, to stochastically introduce auxotrophies (metabolic deficiencies),

216 upon which cells can only continue proliferation by exchanging metabolites. Because plasmid

217 segregation continues until a maximum amount of auxotrophic cells is reached, SeMeCos boost

218 metabolite exchange interactions within the communities. Indeed, compared to wild-type cell

219 communities, SeMeCos are characterised by increased metabolite export, an increase in

220 extracellular metabolite concentrations, and increased metabolic interactions ${ }^{38}$. Despite

221 boosting metabolite exchange interactions, SeMeCos still exploit the native metabolite export

222 and import capacities of yeast cells and do not have artificially altered metabolic pathways or

223 metabolite sensing properties ${ }^{38,41,51}$ (Fig. 2a).

224 Analysing chronological lifespan of SeMeCos (Fig. 2b), we observed that in comparison to the

225 isogenic wild-type strain, SeMeCos were long-lived, as assessed by monitoring colony forming

226 units (CFUs) over time. SeMeCos lost more CFUs immediately after reaching the stationary

227 phase, but in later time-points contained more CFUs and were alive after the wild-type cultures

228 lost viability (Fig. 2c, unpaired two-sided $t$-test, $p$-value $=0.00661$ at day 18 of culture; CLS p-

229 values listed in Supplementary File 4). To have an independent assessment of survival, we

230 also monitored cell viability using Live/Dead ${ }^{\mathrm{TM}}$ cell staining assays. At late timepoints, SeMeCos

231 also contained significantly more viable cells (Supplementary Fig. 4a, unpaired two-sided $t$ -

232 test; CLS p-values listed in Supplementary File 4). Finally, we exploited the situation where

233 due to the higher cell density and proximity, metabolite exchange is amplified in colonies

234 compared to liquid cultures. Yeast cells survived much longer in colonies than in liquid culture

235 ( 65 vs 20 days). Moreover, also in the colony, SeMeCos had a significantly longer CLS than

236 the isogenic wild-type cells (Fig. 2c, unpaired two-sided $t$-test, $p$-value $=0.0338$ at day 65 of

237 growth, CLS p-values listed in Supplementary File 4). We ruled out that the difference in

238 lifespan between SeMeCos and wild-type was explained by differences in $\mathrm{pH}$, a common

239 confounder of lifespan experiments ${ }^{52}$ (Supplementary Fig. 4b, unpaired two-sided $t$-test, $p$ -

240 values listed in Supplementary File 5). Moreover, our data suggests that SeMeCo cells were

241 not long-lived due to amino acid starvation, a known lifespan extending intervention ${ }^{53}$. Indeed, 
bioRxiv preprint doi: https://doi.org/10.1101/2022.03.07.483228; this version posted March 7, 2022. The copyright holder for this preprint

(which was not certified by peer review) is the author/funder, who has granted bioRxiv a license to display the preprint in perpetuity. It is made available under aCC-BY 4.0 International license.

242 corresponding to the increased exchange of metabolites, the extracellular medium was more

243 metabolite rich in stationary SeMeCos than in wild-type cells, including H, L, M and U (Fig. 2d,

244 Supplementary Fig. 5, unpaired two-sided Wilcoxon Rank sum test and multiple testing

245 correction BH method, adjusted p-values in Supplementary File 6).

The lifespan extension in SeMeCos is mediated by a paracrine mechanism

249

250

Next, we tested if the lifespan extension is associated with specific metabotypes, i. e. with specific metabolic dependencies between cells in a community. The SeMeCo model is based

on the stochastic segregation of four plasmid-encoded auxotrophic marker enzymes (HIS3,

LEU2, URA3 and MET15) resulting in 16 metabotypes (metabolic genotypes, Fig. 2a)

distinguishable by genetics. Because of the coupling to other metabolic processes, the 16 metabotypes are connected to broad changes in metabolism and, together, affect differential expression of $2 / 3$ rds of the genome ${ }^{54}$. We monitored occurrence and relative contributions of the different auxotrophies to the ageing SeMeCo cultures over time. Generally, we observed that the proportion of prototrophic cells declined over time and that during the late stationary phase $\sim 98 \%$ of viable cells were auxotrophs. Among the auxotrophs, the met15 segregants dominated, and increased in relative abundance with time (Fig. 3a, paired two-sided $t$-test, pvalues in Supplementary File 7).

262 To test the contribution of the individual auxotrophies to the lifespan extension, we next 263 generated additional versions of the SeMeCo communities, in which each one of the 264 auxotrophic markers (HIS3, LEU2, URA3 or MET15) was genomically repaired, and hence, only 265 three plasmids segregate ('3p-SeMeCos') (Fig. 3b). The genomic repair of HIS3, LEU2 or 266 URA3 did not significantly change the lifespan of SeMeCos, whereas the 3p-SeMeco in which 267 the MET15 locus was no longer segregating had significantly shorter lifespan (Fig. 3c, unpaired 268 two-sided Wilcoxon Rank sum test, p-value at day 20 of culture for: SeMeCo vs wt $=0.0294$ 
bioRxiv preprint doi: https://doi.org/10.1101/2022.03.07.483228; this version posted March 7, 2022. The copyright holder for this preprint

(which was not certified by peer review) is the author/funder, who has granted bioRxiv a license to display the preprint in perpetuity. It is made available under aCC-BY 4.0 International license.

SeMeCo vs HIS3-SeMeCo $=0.3428$, SeMeCo vs LEU2-SeMeCo $=0.3428$, SeMeCo vs URA3-

270 SeMeCo $=0.2000$, SeMeCo vs MET15-SeMeCo $=0.0210 ;$-values across CLSs are listed in

271 Supplementary File 8). Moreover, SeMeCos that only segregate the MET15 marker (pM-

272 SeMeCo) also had increased lifespan compared to wild-type communities (Supplementary Fig.

273 6, unpaired two-sided Wilcoxon Rank Sum test, $p$-value at 28 days of culture $=3.27 \mathrm{e}-05 ; \mathrm{p}$ -

274 values across CLS are listed in Supplementary File 9). Both the accumulation of the met15

275 segregants during the CLS, and the loss of the phenotype when MET15 is not segregating,

276

associated the lifespan extension with the methionine biosynthetic pathway and the organic

277 sulphur cycle.

278

279 Methionine and other sulphur containing amino acids have repeatedly been linked to ageing,

280 and typically it was a methionine restriction that caused a lifespan extension in model organisms

$281{ }^{55-60}$. Interestingly however, the high prevalence of met15 $\Delta$ cells in SeMeCos and the high

282 concentration of methionine produced by cells in the growth media did not suggest that an

283 underlying methionine restriction would apply. To confirm that the fundamental mechanism of

284 our observation is not methionine restriction, we conducted a control experiment, where we

285 supplemented met $15 \Delta$ cells with $2 \mathrm{~g} / \mathrm{L}$ of methionine. Despite the high methionine levels, we

286 observed a robust lifespan extension in met15 $\Delta$ cells (Supplementary Fig. 6, unpaired two-

287 sided Wilcoxon Rank Sum test, $p$-value at 28 days of culture $=3.27 \mathrm{e}-05 ; \mathrm{p}$-values across CLS

288 are listed in Supplementary File 9). In search of an alternative explanation, we found evidence

289 for a paracrine effect. We performed an independent CLS experiment, comparing SeMeCos and

290 '3p-SeMeCos' unable to segregate the MET15 locus, confirmed the dependency of the lifespan

291 extension on the organic sulphur cycle pathway (Supplementary Fig. 7, unpaired one-sided

292 Wilcoxon Rank Sum test, p-values in Supplementary File 10), and coupled the CFU analysis

293 with metabotyping analysis (see Methods). Strikingly, we noted that the presence of the met15

294 cells significantly increased the maximum lifespan of the other cells in the community (Fig. 3d-e,

295 unpaired one-sided Wilcoxon Rank Sum, p-values in Supplementary File 11). 
Lifespan extension in cooperating communities is mediated by an exometabolome rich

\section{in protective metabolites}

300

301 To explore the cell-extrinsic factors that mediate the lifespan extension phenotype, we started

by dissecting the metabolic changes emerging when cells metabolically interact. First, we simulated the likely flux changes using a community-adapted version of the flux balance analysis (FBA) that allows monitoring the exchange of metabolites between cells ${ }^{38}$. We simulated the exchange of metabolites between a prototroph and each of the 15 auxotrophic metabotypes that emerge from all possible combinations of $H, L, U$ and $M$ auxotrophies

307 (Supplementary Fig. 8a). The community-FBA revealed that interactions between MET15 and met15 cells cause broad metabolic flux changes affecting a range of metabolic pathways, including central metabolism. The broad response involves not only downstream effects of metabolism intracellularly but, in addition to methionine, also results in the exchange of a

311 plethora of other metabolites. (Supplementary Fig. 8b, Supplementary Fig. 9,

312 Supplementary File 12). This result opened the possibility that it is not only methionine 313 exchange itself, but the metabolic changes introduced by the metabolic cooperation that cause 314 the lifespan extension. In order to get a deeper understanding of the pathways involved, we 315 continued with proteomics analysis. We extracted proteins from the communities, generated 316 tryptic peptides, and analysed them using microLC-SWATH-MS ${ }^{61}$ and processed the data with 317 DIA-NN ${ }^{62}$. We then performed differential protein expression analysis comparing otherwise 318 identical SeMeCos that differ in the segregation of the MET15 marker (SeMeCos vs MET15319 SeMeCos). We measured proteomes during exponential phase (day 1), early stationary (day 2) and stationary (day 8) growth phases (Fig. 4a). We consistently quantified 1951 proteins, around half the typically expressed yeast proteome ${ }^{63}$. The first principal component (PCA1) in a PCA analysis explained $33 \%$ of the variance and separated the proteomes according to growth 
bioRxiv preprint doi: https://doi.org/10.1101/2022.03.07.483228; this version posted March 7, 2022. The copyright holder for this preprint

(which was not certified by peer review) is the author/funder, who has granted bioRxiv a license to display the preprint in perpetuity. It is made available under aCC-BY 4.0 International license.

323 phase. The second principal component (PCA2), which accounts for a further $23 \%$ of the

324 variance, separated the samples based on whether or not the communities segregated the

325 MET15 marker (SeMeCos vs MET15-SeMeCos and wild-type, respectively) (Fig. 4b,

326 Supplementary Fig. 10). Moreover, a comparison of the different communities revealed that

327 most of the differential protein expression occurs when MET15 and met15 cells interact (Fig.

328 4c, Supplementary Fig. 11, unpaired two-sided $t$-test and multiple testing correction with $\mathrm{BH}$

329 method, adjusted p-values in Supplementary File 13). A Gene Set Enrichment Analysis

330 (GSEA) ${ }^{64}$ revealed that $>50 \%$ of the differentially expressed proteins (unpaired two-sided $t$-test,

$331 \mathrm{BH}$ adjusted $\mathrm{p}$-value < of 0.05$)$ ) comprised gene ontologies (GO) belonging to metabolic

332 processes (Supplementary Fig. 12, Supplementary File 14). Mapping of metabolic enzyme

333 expression levels to the metabolic network allowed visualisation of the changes in metabolism

334 that span over central metabolism and intermediate metabolism, in communities where MET15

335 and met15 $\Delta$ cells interact (Fig. 4d, Supplementary Fig. 13). Continuing with a pathway-centric

336 analysis of the proteome did point our attention to glycolysis. Enzymes associated with the

337 glycolysis pathway were generally upregulated in the communities that contained MET15

338 segregants (Fig. 4e). Moreover, an increase in the expression of glycolytic metabolites in

339 stationary cells that typically rely on oxidative phosphorylation for energy production ${ }^{44}$ was

340 somewhat a surprise (Fig. 5a-b). Indeed, both glycolytic activity and glycolytic overflow

341 metabolites are associated with chronological ageing. While glucose restriction itself extends

342 lifespan ${ }^{65}$, the glycolytic overflow metabolites ethanol and acetate both shorten lifespan ${ }^{52,66}$, but

343 another glycolytic overflow metabolite, glycerol, increases CLS ${ }^{67}$. We speculated that a change

344 in release of such metabolites might very well change the lifespan of cells that share a common

345 metabolic environment. We therefore measured ethanol, acetate and glycerol in the

346 exometabolome of the different SeMeCos and wild-type communities during CLS. In the

347 stationary phase, levels of all three metabolites were higher in the communities where MET15

348 and met15 $\Delta$ segregants interacted. Most striking changes were observed for glycerol, whose

349 levels were $\sim 8$ fold increased, whilst ethanol and acetate levels were $\sim 2$ fold higher (Fig. $5 \mathbf{b}$ i), 
bioRxiv preprint doi: https://doi.org/10.1101/2022.03.07.483228; this version posted March 7, 2022. The copyright holder for this preprint

(which was not certified by peer review) is the author/funder, who has granted bioRxiv a license to display the preprint in perpetuity. It is made available under aCC-BY 4.0 International license.

350

351

352

353

354

355

356

357

358

359

360

361

362

363

364

365

366

367

368

369

370

371

372

373

374

375

376

unpaired two-sided $t$-test, p-values in Supplementary File 15). In order to explain the sources

of the increase in glycerol, we studied the intracellular metabolome. SeMeCos revealed

concentration changes in upper and lower glycolytic metabolites across all growth phases: the

most significant changes were however detected in the glycerol-associated three carbon phosphates (G3P, DHAP, and PEP) in the stationary phase. These were increased specifically

in the communities where MET15 and met15 $\Delta$ cells interacted (Fig. 5b ii), unpaired two-sided $t$ -

test, p-values in Supplementary File 15). In parallel, we conducted oxygen consumption (OC)

analysis. We found that the $\mathrm{OC}$ was reduced in the communities containing the MET15

segregants (Fig. 5c, unpaired two-sided Wilcoxon Rank Sum test, p-values in Supplementary

File 16). The three results were all consistent with the accumulation of glycerol in the

extracellular medium: glycolytic enzymes and glycerol precursors were up, while respiratory

metabolism, required for the use of a non-fermentable carbon source as glycerol, was reduced.

To test whether an accumulation of glycerol could be associated with extending lifespan of cooperating communities, we performed a CLS assay where cells were grown in SM media supplemented with glycerol. Glycerol supplementation extended lifespan to 62 days of culture as compared to previously observed (Fig. 3c) $<20$ days in wild-type and MET15-SeMeCos. The SeMeCos also profited from the glycerol treatment, albeit the relative gain was lower than in wild type cells (mean fold change survival to wild-type in early stationary phase of $5.060 \%$, $0.006 \%$ and $0.286 \%$ in SeMeCos, wild-type and MET15-SeMeCos, respectively, at 62 days of culture) (Fig. 5d, unpaired two-sided Wilcoxon Rank Sum test, p-values in Supplementary File 17).

While these results demonstrated that glycerol accumulation is beneficial, the glycerol increase alone might not sufficiently reflect the complexity of the yeast exometabolome. To validate if the community-created exometabolome is indeed mediating the lifespan extension, we hence complemented these results with a media swap experiment. We cultured wild-type communities in SM media until the early stationary phase (48h of culture) and then transferred them to a SeMeCo exometabolome (48h culture media generated in parallel). Control cultures were 
bioRxiv preprint doi: https://doi.org/10.1101/2022.03.07.483228; this version posted March 7, 2022. The copyright holder for this preprint

(which was not certified by peer review) is the author/funder, who has granted bioRxiv a license to display the preprint in perpetuity. It is made available under aCC-BY 4.0 International license.

377 generated by placing wild-type communities back in their own exomebolome (Fig. 5e). Wild-

378 type communities cultured on the exometabolome harvested from SeMeCos showed significant

379 lifespan extension, with mean percentage survival of $20 \%$ in cultures chronologically aged in a

380 SeMeCo exometabolome vs $2 \%$ in cultures chronologically aged in a control wild-type

381 exometabolome, representing a 10-fold increase in CFU formation at 18 days of culture, (Fig.

382 5e, unpaired two-sided Wilcoxon Rank Sum test; $p$-value $=0.0286$ at day 18 of culture, $p$-values

383 across CLS in Supplementary File 18). Hence, the metabolic changes emerging when MET15

384 met15 $\Delta$ cells interact generate a pro-survival metabolic environment that extends lifespan of all

385 cells in a community.

386

387

388

Discussion

389

390

The classical view of the metabolic network is the one of a biochemical network operating inside

the cell. However, with increased understanding of single cell properties, microbial landscapes

and phenotypic heterogeneity this view is rapidly evolving ${ }^{68}$. The individual cell is increasingly

seen to be part of a metabolic environment spanning across cells, and thus, metabolite

exchange interactions between cells are an essential part of metabolism ${ }^{32,69,70}$. In microbes,

metabolic networks span not only over single, but also over multiple species that interact within

microbial communities ${ }^{36,49,71-73}$. The degree of metabolite exchange within those communities

appears to be extensive. For instance, a majority of microbes are uncultivable outside their

community environments, with metabolic co-dependencies being one of the key reasons ${ }^{74}$.

399 Another interesting observation is that from all 12,538 microbial communities sequenced as part

400 of the Earth Microbiome project ${ }^{75}$ only 6 contained no amino acid auxotrophs ${ }^{38}$. The

401 interactions between amino auxotrophs and prototrophs is hence a common situation in

402 microbial communities, which also shows that amino acids are effectively exchanged all the 403 time. 
bioRxiv preprint doi: https://doi.org/10.1101/2022.03.07.483228; this version posted March 7, 2022. The copyright holder for this preprint

(which was not certified by peer review) is the author/funder, who has granted bioRxiv a license to display the preprint in perpetuity. It is made available under aCC-BY 4.0 International license.

404

405 In ecology, metabolite exchange interactions can lead to competition or cooperativity ${ }^{21,23}$, but in

406 any case, they have fundamental physiological implications. For instance, we have previously

407 shown that cells that uptake lysine from the environment mount better protection against

408 oxidants ${ }^{37}$, or that the presence of auxotrophs enriches metabolic environments and increases

409 drug tolerance ${ }^{38}$. Despite being fundamentally important in modulating cellular processes that

410 also impact on ageing - in particular to growth rate, metabolic signalling, and stress tolerance -

411 to our knowledge, the impact of metabolic intercellular interactions has barely been studied in

412 the context of cellular ageing and lifespan. Indeed, studying the physiological impact of

413 metabolite exchange interactions is technically challenging. Metabolite exchange interactions

414 between cells are not captured by many typical single-cell techniques, such as microscopic

415 imaging or single cells RNA sequencing, nor does the concentration of a metabolite explain

416 whether it was produced or consumed by the analysed cell. Moreover, the export and import of

417 metabolites can not be prevented without imposing major metabolic constraints. We herein

418 hence address this problem by using a combination of various omic, metabolic modelling and

419 genetic techniques, and use synthetic SeMeCo communities to boost metabolite exchange

420 interactions. It is important to stress here that SeMeCos do not rely on new or artificial

421 metabolite exchange interactions to yeast cells; they are based on the exchange of metabolite

422 intermediates, that are a result of the native biosynthetic capacity of yeast, which is boosted

423 through the progressive segregation of plasmids ${ }^{41,51}$. Certainly, as a tool of synthetic biology,

424 SeMeCo will not capture all features of natural metabolite exchange interactions. Indeed, with

425 the increasing amount of auxotrophies, SeMeCos become less metabolically versatile

426 compared to prototrophic wild-type cells. However, SeMeCos are one of the very few tools at

427 hand that allow tracing of metabolite exchange between cells, that can flexibly switch between

428 metabolite uptake and consumption. SeMeCos hence prove to be highly useful for studying the

429 physiological consequences of metabolite exchange interactions, by enabling us to boost and

430 trace them. 
bioRxiv preprint doi: https://doi.org/10.1101/2022.03.07.483228; this version posted March 7, 2022. The copyright holder for this preprint

(which was not certified by peer review) is the author/funder, who has granted bioRxiv a license to display the preprint in perpetuity. It is made available under aCC-BY 4.0 International license.

431

432 In studying metabolite exchange interactions in the context of chronological lifespan in yeast, we

433 made two observations that triggered our curiosity. The first was that metabolites exported

434 during the exponential phase, label the cells during the stationary phase, reflecting their import

435 by post-mitotic cells. In the batch-culture, there exists hence a 'cross-generational' exchange of

436 metabolites. Ecologically speaking, the batch culture might have been seen as an artificial

437 situation. However, in natural yeast colonies, old and young yeast cells co-exist in close

438 physical distance ${ }^{76}$. That means that metabolite exchange interactions are even more likely in a

439 natural colony than in batch culture. It is consistent with this notion, that a switch from liquid

440 culture to colony growth tripled the chronological lifespan of our cells. To us, this result hence

441 implies there could be extensive metabolic interactions that apply to both growth and ageing

442 phases of the yeast cell communities.

443 The second observation was that upon boosting metabolic interactions by using the SeMeCo

444 model, a significant extension of the CLS was achieved. Studying the metabotype composition

445 within SeMeCos attributed a special role to the methionine biosynthetic pathway that is part of

446 the organic sulphur cycle. We observed that cells that had segregated the MET15 plasmid

447 comprised the highest proportion of long-lived cells in ageing communities. Sulphur amino acids

448 include methionine, cysteine, homocysteine and taurine ${ }^{77}$ and have previously been associated

449 with lifespan extension. Methionine restriction in particular can extend lifespan in a number of

450 organisms ${ }^{55-60}$, prevent the development of a variety of diseases ${ }^{78}$ and influence response to

451 anti-cancer therapies ${ }^{79,80}$. Our results differed, however, from many of these studies in a

452 fundamental aspect, as they did not indicate the lifespan extension is caused by methionine

453 restriction. We hence speculated that another mechanism could be at play in the communal

454 cells. The key observation which eventually led to a better understanding of the mechanism,

455 was that the presence of the MET15 segregants did not only increase their own lifespan, but

456 also the lifespan of the other cells found within SeMeCos. This result strongly suggested that

457 only part of the answer is to be found in the intracellular metabolic reconfiguration in the MET15 
bioRxiv preprint doi: https://doi.org/10.1101/2022.03.07.483228; this version posted March 7, 2022. The copyright holder for this preprint

(which was not certified by peer review) is the author/funder, who has granted bioRxiv a license to display the preprint in perpetuity. It is made available under aCC-BY 4.0 International license.

458 segregants, and that we need to search for a paracrine effect, like a change in the extracellular

459 metabolite pool, to understand the lifespan extension of the entire community.

460 In order to identify the metabolic changes, we combined metabolite profiling, proteomics and

461 genome-scale metabolic modelling. We detected widespread metabolic changes in the

462 communities containing MET15 segregants, but were most intrigued by an upregulation of

463 glycolytic enzymes, in a growth phase where typically oxidative metabolism dominates. In

464 following this, we confirmed a decrease in oxygen consumption and an 8-fold increase in the

465 glycolytic overflow metabolite glycerol. Glycerol is known as a protective and pro-survival

466 metabolite ${ }^{67}$, and also in our hands, significantly extends the lifespan of both wild-type and

467 SeMeCo communities. Glycerol stimulates several survival-associated processes, including

468 osmoregulation, lipid biogenesis, cell wall integrity ${ }^{81}$ and increase in autophagy ${ }^{67}$, a known

469 regulator of lifespan ${ }^{82}$. It is likely that glycerol extends lifespan in a systematic way. Our data

470 does not exclude the possibility that next to glycerol, other protective metabolites enrich in the

471 communal environment, but it shows that in sum, the protective metabolites compensate for the

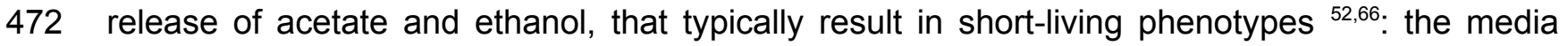

473 collected from SeMeCo cells did extend the chronological lifespan of wild-type cells. Our results

474 have interesting evolutionary implications. It has so far been debated if unicellular organisms

475 would profit from a longer lifespan and if they have been selected for longevity ${ }^{83}$. Our study

476 does not address this question directly, but it reveals an interesting new possibility, in the light

477 that a vast majority of natural microbial communities contain auxotrophs ${ }^{38,74}$. Evolution could

478 increase longevity by selecting for populations of cells that metabolically interact in a way that

479 they generate a protective exometabolome. Specifically, the MET15 segregants, which cannot

480 synthesise methionine and require an organic sulphur source for growth ${ }^{84}$, cannot survive on

481 their own in the absence of methionine producers. They would benefit if the lifespan of

482 methionine producers is extended. Auxotrophy-prototrohy interactions might hence select for

483 longevity in microbial communities, in other words that metabolic dependencies would not only

484 drive species co-occurrence ${ }^{71}$ but boost their longevity and evolution. In any case, our results 
bioRxiv preprint doi: https://doi.org/10.1101/2022.03.07.483228; this version posted March 7, 2022. The copyright holder for this preprint

(which was not certified by peer review) is the author/funder, who has granted bioRxiv a license to display the preprint in perpetuity. It is made available under aCC-BY 4.0 International license.

485 prompt future studies for closely examining the exometabolome as a cause of lifespan

486 extension, specifically when metabolic interventions, such as metabolite

487 restriction/supplementation or metabolic modulating drug treatments are applied.

488

489 In summary, we uncover a protective metabolic paracrine effect occurring in metabolically 490 interacting eukaryotic microbial communities. Glycolytic methionine consumer cells enrich the 491 intercellular space for the pro-survival metabolite glycerol, increasing the survival of their 492 producer counterparts and overall community longevity. Impairment or inability to metabolically 493 interact drives cellular dysfunction, which accompanies ageing and disease, therefore dissecting 494 the metabolic dynamics and emerging metabolic environment when cells metabolically interact 495 will aid the development of therapies targeting these processes. Often lifespan extension is associated with restriction conditions, but our data shows that a differentiated view is also necessary, as simple nutritional interventions like the exchange of amino acids can have broad changes in the metabolic network dynamics, reflected in the exometabolome, and alter lifespan this way. Future investigations are necessary to determine how broadly this situation impacts on other nutritional and/or metabolic contexts influencing lifespan.

501

502

503

\section{Methods}

504

505 Yeast cultivation and growth assays

506

507 Plasmids and strain construction

508 The haploid BY4741 S. cerevisiae strain (his3 $\Delta 1$, leu2 $\Delta 0$, ura3 $\Delta 0$, met15 $\Delta 0$ ) was used to 509 generate all subsequent strains used in the study. Prototrophy was restored either by genomic 510 knock-in, with primer design based on information from Brachmann et al. $1998^{42}$, or plasmid

511 complementation generated by Mülleder et al. $2016^{85}$, followed by standard cloning and yeast 
bioRxiv preprint doi: https://doi.org/10.1101/2022.03.07.483228; this version posted March 7, 2022. The copyright holder for this preprint

(which was not certified by peer review) is the author/funder, who has granted bioRxiv a license to display the preprint in perpetuity. It is made available under aCC-BY 4.0 International license.

512 transformation techniques ${ }^{86}$. Primers and plasmids details are in Tables S2 and S3,

513 respectively.

514

515 SeMeCo generation and culture

516 The generation and culture of SeMeCos was performed as previously described ${ }^{38}$. The $\mathrm{pH}, \mathrm{pL}$,

$517 \mathrm{pU}$ and pM plasmid used to generate a SeMeCo strain in the BY4741 background are described

518 in Table S3. All SeMeCo strains were cultured in minimal synthetic (SM) media, composed of

519 yeast nitrogen broth without amino acids (YNB, $6.8 \mathrm{~g} / \mathrm{L}$; Sigma \#Y0626) + 2\% glucose (20 g/L;

520 Sigma \#G8270), so cells rely on the exchange of self-synthesised metabolites for growth and

521 survival. Briefly, cryostocks were streaked onto $\mathrm{SM}+2 \%$ agar medium and cultured at $30^{\circ} \mathrm{C}$ for

5223 days. Then, a micro-colony was diluted in $500 \mu \mathrm{ldH} \mathrm{H}_{2} \mathrm{O}$, and normalised to $\mathrm{OD}_{600 n m}=0.8$. Then,

$5235 \mu \mathrm{l}$ were spotted onto solid SM medium to generate a giant colony. This initial spotting

524 corresponded to $\sim 7.2 \times 10^{4}$ cells using a predefined OD-to-cell number standard curve. Cells

525 were incubated for 2 days at $30^{\circ} \mathrm{C}$, then giant colony generation was repeated, to ensure cells

526 have undergone enough proliferation cycles and plasmid segregation, enabling metabolic

527 cooperation, whilst being continuously kept in an exponential growth phase. Pre-cultures were

528 generated by diluting the giant spots into $1 \mathrm{ml} \mathrm{dH_{2 }} \mathrm{O}$, normalised to $\mathrm{OD}_{600 \mathrm{~nm}}=1 \mathrm{in} \mathrm{SM}$ liquid

529 medium and cultured for 16 hours at $30^{\circ} \mathrm{C}$. Cultures were then generated by diluting the pre-

530 cultures to $\mathrm{OD}_{600 \mathrm{~nm}}=0.1$ in $\mathrm{SM}$ liquid medium and cultured for the duration of the CLS. This

531 relatively high starting $\mathrm{OD}_{600 \mathrm{~nm}}$ ensures cells are kept at a density that minimises disturbing the

532 relative proportions of auxotrophs and prototrophs generated in SeMeCos. Cells were collected

533 for downstream experiments at different growth phases, as indicated in figure legends. The

534 control wild-type (BY4741, quadruple knock-in - HIS3, LEU2, URA3 and MET15) strain followed

535 the exact same procedures as SeMeCos. Strain details are in Table S1.

536 For CLS assays where cells were grown on glycerol, SM was supplemented with 3\% Glycerol

537 (Sigma \# G2025) and 1\% Glucose; SeMeCo generation and respective wild-type controls were 
538 grown on solid SM supplemented with glucose prior to being cultured in SM supplemented with

539 glycerol from pre-culture stage onwards.

540

\section{Knockout strains culture}

542 Knockout strains cultures followed the exact same procedure as described for SeMeCo

543 generation and culture. In the case of metabolic knockout mutants (met15 $\Delta$ ), cells were grown

544 on SM media supplemented with the metabolite for which the strain was biosynthetically

545 impaired (2g/L L-methionine), with respective wild-type controls also being cultured in SM

546 supplemented with the metabolite. Strain details are in Table S1.

547

548

\section{Isotope tracing}

549 Wild-type yeast cells were cultured in SM media supplemented either with ${ }^{12} \mathrm{C}$-glucose $\left({ }^{12} \mathrm{C}\right.$-glu;

swapped for tracing amino acid export/import, using targeted metabolomics ${ }^{50}$ (HPLC-MS/MS),

at different time points post media swap. Control cultures were swapped from SM supplemented with ${ }^{13} \mathrm{C}$-glucose to SM solely supplemented with ${ }^{12} \mathrm{C}$-amino acids $\left({ }^{12} \mathrm{C}-\mathrm{AA}\right.$; Sigma \#Y1896) at

554 standard culturing concentrations.

555

556

\section{Exometabolome exchange}

557 Wild-type and SeMeCo yeast cells were cultured in parallel, in SM media, for 48 hours (until the

558 stationary phase). Culture media was then collected by spinning down cells in each culture at

$5593000 \mathrm{~g}$ for $5 \mathrm{~min}$ at room temperature (RT) followed by supernatant (media) filtering with a 0.22

$560 \mu \mathrm{m}$ syringe filter. Some wild-type culture cell pellets were then gently resuspended in the filtered

561 media (exometabolome) from SeMeCos whilst others were resuspended back in their own

562 filtered media as control. Wild-type cultures in SeMeCos or wild-type exometabolomes were

563 then followed for CLS. 
bioRxiv preprint doi: https://doi.org/10.1101/2022.03.07.483228; this version posted March 7, 2022. The copyright holder for this preprint

(which was not certified by peer review) is the author/funder, who has granted bioRxiv a license to display the preprint in perpetuity. It is made available under aCC-BY 4.0 International license.

\section{Growth assays}

566 Growth was assessed by monitoring biomass formation using optical density absorbance at a

567 wavelength of $600 \mathrm{~nm}\left(\mathrm{OD}_{600}\right)$. $\mathrm{OD}_{600}$ was recorded either manually during the CLS, on a

568 Ultrasepc 2100 pro manual $^{\mathrm{TM}}$ (Amersham Biosciences), or automatically on a plate reader

569 NanoQuant Plate ${ }^{\mathrm{TM}}$, Infinitive 200 PRO (Tecan), every 10 minutes, until cells reached stationary

570 phase, at $30^{\circ} \mathrm{C}$ for growth curve recording. Both maximum growth and time to mid log phase

571 were determined from growth curves using the R 'grothcurver' package ${ }^{87}$.

572

573 Chronologic Lifespan

574

\section{Conventional and High-throughput Colony Forming Unit (CFU) assays}

576 Conventional CFU analysis was performed as described previously ${ }^{88}$ by aliquoting ageing

577 cultures throughout CLS, and plating cells at different dilution factors into solid rich media

578 (YPD), composed of yeast extract (10 g/L; Sigma), peptone (20 g/L; Sigma), dextrose (20 g/L;

579 Sigma) and agar (20 g/L; Sigma). Cells were incubated for 2 days at $30^{\circ} \mathrm{C}$ and the number of

580 CFUs were recorded. Increasing numbers of cultures analysed in parallel required the usage of

581 a high-throughput CFU (HTP-CFU) method as described in ${ }^{89}$. Briefly, $200 \mu \mathrm{L}$ aliquots of ageing

582 culture were loaded into the first column of a 96 -well plate ( 8 cultures in parallel per plate). The

583 rest of the plate was loaded with $100 \mu \mathrm{L}$ of $\mathrm{dH}_{2} \mathrm{O}$. Using a Biomek $\mathrm{NX}^{\mathrm{P}}$ automatic liquid handler

584 (Beckman Coulter), $50 \mu \mathrm{L}$ of the ageing culture from the first column were serially diluted 3-fold

585 across the plate, ensuring each dilution factor was well mixed. Droplets of serially diluted ageing

586 cultures were immediately dispensed onto solid YPD, in quadruplicate (384-well format) using a

587 Singer RoToR HDA pinning robot (Singer Instruments). For this, long-pin 96-density pads were

588 used, making sure that the source plate was revisited before each pin onto the agar. Plates

589 were incubated for 2 days at $30{ }^{\circ} \mathrm{C}$ until patterns of colonies appeared. Images of agar plates

590 were acquired with Pyphe-scan ${ }^{90}$ using an Epson V700 scanner in transmission mode. Plate

591 image analysis and quantification of the number of CFUs in the ageing culture, based on the 
bioRxiv preprint doi: https://doi.org/10.1101/2022.03.07.483228; this version posted March 7, 2022. The copyright holder for this preprint

(which was not certified by peer review) is the author/funder, who has granted bioRxiv a license to display the preprint in perpetuity. It is made available under aCC-BY 4.0 International license.

592 colony patterns observed, were performed using the $\mathrm{R}$ package, DeadOrAlive ${ }^{89}$. In both

593 conventional- and HTP-CFU assays, survival of the different strains was normalised, first to

594 biomass at time of sample collection, as measured by $\mathrm{OD}_{600}$, and then to the survival of the

595 respective wild-type controls at the beginning of the stationary phase (48 hours from the start of

596 culture).

597

598 Live/Dead Staining

599 Cell death was assessed using the LIVE/DEAD ${ }^{\text {TM }}$ Fixable Far Red Dead Cell Stain Kit, for 633

600 or $635 \mathrm{~nm}$ excitation (ThermoFisher Scientific, Cat no. L10120) according to the manufacturer's

601 instructions, followed by high-throughput flow cytometry (HTP-FC). Briefly, an aliquot of 300 uL

602 of each ageing culture was transferred to a 96-deep well plate. Plates were then spun down at

$6033000 \mathrm{~g}$ for $3 \mathrm{~min} \mathrm{RT}$, supernatant was discarded and cells were resuspended in $300 \mathrm{uL}$ of

604 diluted dye (1:1000 diluted stock dye in $\mathrm{dH}_{2} \mathrm{O}$ ), followed by an incubation of 30 minutes in the

605 dark. Cells were then washed in $500 \mathrm{uL}$ of $\mathrm{dH}_{2} \mathrm{O}$, resuspended in $300 \mathrm{uL}$ of $\sim 4 \%$ formaldehyde

606 (dilute 1:10 37\% Formaldehyde in PBS 1x) and incubated $10 \mathrm{~min}$ in the dark. Cells were

607 washed in PBS $1 \mathrm{x}$ and stored in $500 \mathrm{uL}$ fresh PBS $1 \mathrm{x}$ at $4^{\circ} \mathrm{C}$, protected from light, until analysis

608 by HTP-FC. Immediately prior to analysis, samples were sonicated for $20 \mathrm{~s}$ at $50 \mathrm{~W}$ (JSP

609 Ultrasonic Cleaner model US21), and $250 \mathrm{uL}$ were transferred to a 96-well plate for HPT-FC

610 analysis. For HTP-FC, 30,000 cells/sample were measured in a Fortessa X20 Flow cytometer

611 (BD Biosciences), using the HTS plate mode on the DIVA software and a $633 \mathrm{~nm}$ excitation

612 laser to capture the dye staining. Populations of interest were gated using the FlowJo software

613 version 10.3.0. Features of interest (dead and live cell populations) were then exported for

614 further analysis using R studio.

615

616 Metabotyping

617 Metabotype performed as previously described ${ }^{51}$, with the difference that colonies were 618 cryostocked prior to replica-plating, so cells collected at different time points across the CLS 
bioRxiv preprint doi: https://doi.org/10.1101/2022.03.07.483228; this version posted March 7, 2022. The copyright holder for this preprint

(which was not certified by peer review) is the author/funder, who has granted bioRxiv a license to display the preprint in perpetuity. It is made available under aCC-BY 4.0 International license.

619 would be analysed in parallel. Firstly, conventional CFUs were performed as described above.

620 Then 96 individual CFUs per biological replicate were resuspended in $100 \mu \mathrm{l}$ of liquid YPD

621 supplemented with $30 \%$ glycerol in a 96 well plate (Nunc ${ }^{\mathrm{TM}}$ Sigma), as one colony/well, and then

622 incubated at $30^{\circ} \mathrm{C}$ ON prior freezing at $-80{ }^{\circ} \mathrm{C}$. Once all samples across the CLS were

623 collected, plates were defrosted and then replica plated on six plates, containing either (a)

624 complete medium (SM with all four missing nutrients - $2 \mathrm{~g} / \mathrm{L}$ of L-histine, L-uracil and L-

625 methionine and $6 \mathrm{~g} / \mathrm{L}$ of L-leucine, Sigma), (b) SM medium, and plates with SM and all nutritional

626 supplements except (c) L-histidine, (d) L-leucine, (e) L-uracil, or (f) L-methionine. The absence

627 of growth in a particular drop-out medium reflects the clone auxotrophy for that specific

628 metabolite. The combinatorial growth ability in the six different media allows determination of

629 each clone metabotype (total auxotrophies it contains). This method permits identification of all

63016 possible metabotypes resulting from all possible combinations of the four auxotrophies.

631

$632 \mathrm{pH}$ analysis

633 Aliquots of $1 \mathrm{~mL}$ were collected per culture at different time points during the CLS and $\mathrm{pH}$ was

634 measured using a Mettler-Toledo InLab $^{\circledR}$ Micro \& Micro Pro pH electrode coupled to $\mathrm{pH} / \mathrm{lon}$ 635 bench meter SC S220-B (Mettler Toledo).

636

637 Oxygen consumption measurements

638 Ten $\mathrm{mL}$ of CLS cultures were collected during exponential (day 1) and early stationary phase

639 (day 2) and placed into a 10-mL Erlenmeyer flask and stirred at $900 \mathrm{rpm}$ using a magnetic

640 stirrer bar. An oxygen probe (Hanna HI 98193), held with a clamp, was inserted into the flask,

641 resulting in it being completely filled with no remaining air inside it, and the flask was sealed with

642 multiple layers of parafilm. The oxygen saturation of the culture was recorded every $\sim 1$ min for 5

643 min. Oxygen levels were normalised to biomass, as measured by $\mathrm{OD}_{600}$, and to levels of wild-

644 type at the end of measurements (5 min).

645 
649 Metabolomics

650

651 Targeted metabolomics for intracellular glycolytic and TCA intermediates, nucleotides

652 and amino acids

653 Sample preparation

654 Ageing cultures, at several time points reflecting different growth phases, were sampled and $655400 \mathrm{uL}$ of each culture were quenched in $1600 \mathrm{uL}$ dry-ice-cold methanol, into a 48-deep-well 656 plate. This suspension was spun down $\left(600 \mathrm{~g}, 3 \mathrm{~min}, 4^{\circ} \mathrm{C}\right)$, and the supernatant was discarded

657 by inversion, followed by a short spin $\left(600 \mathrm{~g}, 1 \mathrm{~min}, 4^{\circ} \mathrm{C}\right)$ to ensure complete removal of the SN.

658 Cell pellets were immediately placed on dry ice and then transferred to $-80^{\circ} \mathrm{C}$ until analysis.

659 Intracellular metabolites were then extracted as described ${ }^{91}$. Briefly, $140 \mu \mathrm{l} \mathrm{of} \mathrm{10:4} \mathrm{MeOH/water}$

660 were added and vortexed. Then, $50 \mu$ l chloroform was added, followed by $50 \mu$ water and $50 \mu \mathrm{l}$

661 chloroform with thorough mixing in between. Phases were separated by centrifugation at 3,000

$662 g$ for $10 \mathrm{~min}$. The aqueous phase was recovered and used without further conditioning. One

663 microlitre was injected for HPLC-MS/MS analysis. Before analysis by HPLC-MS/MS the order of

664 samples was randomised and during analysis a quality control sample (QC) was assessed 665 every 24 samples.

\section{Sample acquisition}

667 Metabolites were resolved on an Agilent 1290 liquid chromatography system by HILIC coupled

668 to an Agilent 6470 triple quadrupole instrument operating in dynamic MRM mode, as previously

669 described ${ }^{43}$. In short, the gradient program started at 30\% B (100 mM ammonium carbonate)

670 and was kept constant for 3 min before a steady increase to $60 \%$ B over 4 min. Solvent B was

671 maintained at $60 \%$ for 1 min before returning to initial conditions. The column was washed and 
bioRxiv preprint doi: https://doi.org/10.1101/2022.03.07.483228; this version posted March 7, 2022. The copyright holder for this preprint

(which was not certified by peer review) is the author/funder, who has granted bioRxiv a license to display the preprint in perpetuity. It is made available under aCC-BY 4.0 International license.

672 equilibrated for $2 \mathrm{~min}$ resulting in a total analysis time of $10 \mathrm{~min}$. We used acetonitrile as solvent

673 A and a Waters BEH Amide column $(2.1 \times 100 \mathrm{~mm}, 1.7 \mu \mathrm{m}$ particle size $)$ for separation. The

674 flow rate was set to $0.3 \mathrm{ml} / \mathrm{min}$ and column temperature to $35 \mathrm{C}$. Compounds were identified by

675 comparing retention time and fragmentation patterns with analytical standards. Metabolite

676 quantifications were then normalised per biomass, as measured by $\mathrm{OD}_{600}$, at the time of 677 collection.

678

679 Targeted metabolomics for intracellular and extracellular amino acids \& uracil

680

quantification

681

Sample preparation

682

Ageing cultures, at several time points reflecting different growth phases, were sampled and

$500 \mathrm{uL}$ of each culture were collected into a 96-deep-well plate for amino acid \& uracil profiling.

684

Samples were centrifuged at $4,000 \mathrm{~g}$ for $3 \mathrm{~min}$ and supernatants (SN) were transferred into a

685

new 96-deep-well plate for extracellular metabolite profiling, whilst cell pellets were washed

686

once in $\mathrm{dH}_{2} \mathrm{O}$, spun down at 4,000 $\mathrm{g}$ for $3 \mathrm{~min}$ and $\mathrm{SN}$ was discarded (followed by a $1 \mathrm{~min}$ spin

687

for complete removal of SN) for later intracellular metabolite profiling. Both cell pellets and SN

688

were immediately frozen in dry ice and samples were then stored at $-80^{\circ} \mathrm{C}$ until analysis.

689

The amino acid extraction and uracil extraction, separation and detection protocols were adapted from ${ }^{50}$. Briefly, $200 \mu$ of $80 \%$ ethanol at $80^{\circ} \mathrm{C}$ were added to the yeast pellets.

691 Samples were heated for $2 \mathrm{~min}$ at $80^{\circ} \mathrm{C}$, vigorously mixed on a vortex mixer and incubated for

692 further $2 \mathrm{~min}$ at $80^{\circ} \mathrm{C}$ followed by vigorous vortexing. The extracts were removed from debris by

693 centrifugation at $12,000 \mathrm{~g}$ for $5 \mathrm{~min}$. SN were also centrifuged at $12,000 \mathrm{~g}$ for $5 \mathrm{~min}$ to further

694 purify samples from any debris. Before analysis by HPLC-MS/MS the order of samples was

695 randomised and during analysis a quality control sample (QC) was assessed every 24 samples.

696

697

698 
bioRxiv preprint doi: https://doi.org/10.1101/2022.03.07.483228; this version posted March 7, 2022. The copyright holder for this preprint

(which was not certified by peer review) is the author/funder, who has granted bioRxiv a license to display the preprint in perpetuity. It is made available under aCC-BY 4.0 International license.

\section{Sample acquisition}

700 Analysis by LC-MS/MS, amino acids \& uracil were separated by hydrophilic interaction liquid

701 chromatography (HILIC) using an ACQUITY UPLC BEH amide column (130A ${ }^{\circ}, 1.7 \mathrm{~mm}, 2.1$

$702 \mathrm{~mm} \mathrm{X} 100 \mathrm{~mm}$ ) on a liquid chromatography (Agilent 1290 Infinity) and tandem mass

703 spectrometry (Agilent 6460) system. Buffer A was composed of 50:50 acetonitrile/water

704 (Greyhound Bio-012041, Greyhound 23214125), 10 mM ammonium formate (Fluka, Cat. No.

705 14266), $\quad 0.176 \%$ formic acid (Fluka, Cat. No. O6454) and buffer B of 95:5:5

706 acetonitrile/methanol/water (Greyhound BIO-13684102), $10 \mathrm{mM}$ ammonium formate, 0.176\%

707 formic acid. The gradient elution was performed at a constant flow rate of $0.9 \mathrm{ml} / \mathrm{min}$. Starting

708 conditions were $85 \%$ buffer $\mathrm{B}$, after 0.7 min the concentration of buffer $\mathrm{B}$ was decreased

709 gradually to $5 \%$ until $2.55 \mathrm{~min}$ and kept for a further $0.05 \mathrm{~min}$ before returning to initial

710 conditions. The column was then equilibrated, resulting in a total runtime of $3.25 \mathrm{~min}$.

711 Compounds were identified by matching retention time and fragmentation (MS2) with

712 commercially obtained standards (Sigma-Aldrich, Cat. No. LAA21). Signals for free amino acids

713 were then acquired in dynamic SRM mode in the MassHunter Software Agilent. Amino acid \&

714 uracil quantifications were then normalised per biomass, as measured by $O D_{600}$, at the time of

715 collection.

716 Extracellular amino acids and uracil data from wild-type in exponential phase are a re-analysis

717 of data in ${ }^{38}$; experiments, including cell culture, metabolite extraction and sample acquisition,

718 were performed in parallel.

719

720

HPLC method for ethanol, acetate and glycerol exometabolome quantification

\section{Sample preparation}

722 Frozen SN in 96 deep-well plates (collected as described above for amino acid and uracil

723 analysis) were defrosted and kept shaking using plate shaker for 20 minutes 900 rpm room

724 temperature, just before the filtration, using a multiscreen filtered plate with 0.45 um durapore 
bioRxiv preprint doi: https://doi.org/10.1101/2022.03.07.483228; this version posted March 7, 2022. The copyright holder for this preprint (which was not certified by peer review) is the author/funder, who has granted bioRxiv a license to display the preprint in perpetuity. It is made available under aCC-BY 4.0 International license.

725 membrane (MVHVN4525) and Strata well plate manifold

726 (https://phenomenex.blob.core.windows.net/documents/863d86a0-3aba-4591-979b-

727 bf54b1188038.pdf) and a Welch vacuum pump.

728

729 Sample acquisition

730 The target compounds were quantified using a Shimadzou Prominance HPLC

731 (https://www.ssi.shimadzu.com/products/liquid-chromatography/prominence-hplc.html)

732 equipped with a refractive index detector RID20A and a Sil20-ACT auto sampler with a 96 well

733 plate injector tray. The separation was performed on an Agilent Hi-plex $\mathrm{H}$ column

734 (https://www.agilent.com/cs/library/applications/5990-8801EN\%20Hi-Plex

$735 \% 20$ Compendium.pdf). The temperature of the column and detector was 50 and $41{ }^{\circ} \mathrm{C}$,

736 respectively. The eluent was $0.00125 \mathrm{~N} \mathrm{H} 2 \mathrm{SO} 4$ in Type 1 water $(0.6 \mathrm{~mL} \mathrm{~min}-1)$. The samples

737 were kept in 96 well plates (https://www.sarstedt.com/en/products/laboratory/cell-tissue-

738

culture/cultivation/product/83.3926/)

covered

with

silicone

mat

739 (https://www.phenomenex.com/Products/Part/AH0-8633) at $4{ }^{\circ} \mathrm{C}$ in the autosampler prior the

740 injection for no longer than 2 days. 5 uL was injected from the samples / well plates as well as

741 standard compounds. The method works with 26 minutes cycle time. To keep the retention

742 times and detector response constant $5 \mathrm{~L}$ of eluent was mixed in one batch.

743 For the data analysis the Shimadzou data processing software was used. Target compounds

744 were identified by using automatic retention time matching with individual standards of in the

745 house overflow metabolite library dissolved in SD minimal media. Compound concentrations

746 were calculated using peak area integration with pre-optimized integration parameters and

747 external calibration for each compound. All the calibration curves showed high linearity R2 >

7480.9999 at 3 orders of magnitude concertation range. The integration and compound

749 identification were manually overviewed. Data was then exported and further processed using

750 R. Metabolite quantifications were then normalised per biomass, as assessed by $\mathrm{OD}_{600}$, at the

751 time of collection. 
bioRxiv preprint doi: https://doi.org/10.1101/2022.03.07.483228; this version posted March 7, 2022. The copyright holder for this preprint (which was not certified by peer review) is the author/funder, who has granted bioRxiv a license to display the preprint in perpetuity. It is made available under aCC-BY 4.0 International license.

752

753 Proteomics

754 Sample preparation

755 Ageing cultures, at several time points reflecting different growth phases, were sampled and

756500 uL of each culture were collected into a 96-deep-well plate. Samples were centrifuged at

$7574,000 \mathrm{~g}$ for $3 \mathrm{~min}$ and supernatants (SN) were discarded. Samples were centrifuged again at

$7584,000 \mathrm{~g}$ for $1 \mathrm{~min}$ to fully remove any residual SN. Cell pellets were immediately placed on dry

759 ice before being stored at $-80^{\circ} \mathrm{C}$, until all samples were collected. Sample preparation for

760 proteomics was performed as previously described ${ }^{61}$. Briefly, cell pellets were processed in a

761 bead beater for $5 \mathrm{~min}$ at 1,500 r.p.m. (Spex Geno/Grinder), in a lysis buffer where proteins were

762 denatured in $8 \mathrm{M}$ urea (Sigma-Aldrich, 33247) plus $0.1 \mathrm{M}$ ammonium bicarbonate (Sigma-

763 Aldrich, 09830) at $\mathrm{pH}$ 8.0. Samples were spun down for $1 \mathrm{~min}$ at 4000 r.p.m, before they were

764 reduced in $5 \mathrm{mM}$ dithiothreitol (Sigma-Aldrich, 43815) for $1 \mathrm{~h}$ at $30^{\circ} \mathrm{C}$ and then alkylated in 10

$765 \mathrm{mM}$ iodoacetamide (Sigma-Aldrich, 11149) for $30 \mathrm{~min}$ at RT protected from light. Samples were

766 diluted to less than $1.5 \mathrm{M}$ urea in $0.1 \mathrm{M}$ ammonium bicarbonate at $\mathrm{pH} 8.0$, before proteins were

767 digested overnight at $37^{\circ} \mathrm{C}$ with trypsin (Promega, V511X). Trypsin was neutralised with $1 \%$

768 formic acid (FA) (Fisher Scientific, 13454279), before peptides were cleaned-up in 96-well

769 MacroSpin plates (Nest Group): 1. plates were first equilibrated in a series of Methanol (1x)

770 (Greyhound Chromatography, BIO-13684102), 50\% ACN (2x) (Greyhound Chromatography,

771 Bio-012041-2.5L), and 3\% ACN 0.1\% FA (2x), between each wash plates were spun down for 1

$772 \mathrm{~min}$ at $100 \mathrm{~g}$ and flow through was discarded; 2. samples were loaded into the plates and

773 peptides were cleaned-up in a series of $3 \% \mathrm{ACN}, 0.1 \% \mathrm{FA}(3 \mathrm{x})$, between each wash samples

774 were spun down for $1 \mathrm{~min}$ at $100 \times \mathrm{g}$ and flow through was discarded; 3. peptides were eluted

775 into a new collection plate with $50 \%$ ACN (3x) and spun dried overnight at RT in speed vacuum.

776 Peptides were then dissolved in $40 \mathrm{uL}$ of $3 \%$ ACN $0.1 \%$ FA. Peptide concentration was

777 measured at Absorbance $280 \mathrm{~nm}$ using the Lunatic (Unchained Labs).

778 
bioRxiv preprint doi: https://doi.org/10.1101/2022.03.07.483228; this version posted March 7, 2022. The copyright holder for this preprint (which was not certified by peer review) is the author/funder, who has granted bioRxiv a license to display the preprint in perpetuity. It is made available under aCC-BY 4.0 International license.

\section{Sample acquisition}

780 The digested peptides were analysed on a nanoAcquity (Waters) (running as $5 \mu \mathrm{min}^{-1}$

781 microflow liquid chromatography) coupled to a TripleTOF 6600 (SCIEX). Protein digest $(2 \mu \mathrm{g})$

782 was injected and the peptides were separated with a 23 min non-linear gradient starting with $4 \%$

783 acetonitrile in $0.1 \%$ formic acid and increasing to $36 \%$ acetonitrile in $0.1 \%$ formic acid. A Waters

784 HSS T3 column $(150 \mathrm{~mm} \times 300 \mu \mathrm{m}, 1.8 \mu \mathrm{m}$ particles $)$ was used. The DIA method consisted of

785 an MS1 scan from m/z 400 to m/z 1250 (50 ms accumulation time) and 40 MS2 scans (35 ms

786 accumulation time) with a variable precursor isolation width covering the mass range from $\mathrm{m} / \mathrm{z}$

787400 to $\mathrm{m} / \mathrm{z}$ 1250. Data quantification was performed using DIA-NN version 1.7 .1 software ${ }^{62}$.

Post-processing data analysis was conducted in $\mathrm{R}^{92}$.

789

790

Genome-scale metabolic modelling (Flux balance analysis)

791

Constructing auxotroph-prototroph community metabolic models

792 The community metabolic models were reconstructed using the approach from our previous

793 study ${ }^{38}$. Briefly, the genome-scale metabolic model of S. cerevisiae ${ }^{93,94}$ was used to create

794 auxotrophic strain models by switching off respective metabolic reactions. Then the reactions

795 from auxotroph $(\mathrm{H}, \mathrm{L}, \mathrm{U}$ and/or $\mathrm{M})$ and prototroph (WT) models were combined to make the

796 community, using the compartment per guild approach, where both strains were treated as

797 separate compartments and metabolic exchange between strains were allowed. The community

798 biomass was the combined biomass of all strains. The Cobra toolbox ${ }^{95}$ was used to perform the

799 model simulations.

800

801 Data analysis and statistics

802 All statistical analyses were done in R (R Core Team, 2015) ${ }^{92}$ using specific packages as 803 indicated throughout the methods section. For the basic data manipulation and visualisation we 804 used the $\mathrm{R}$ tidyverse package compilation and for statistical analysis we used the $\mathrm{R}$ ggpubr 805 package. Hypothesis testing to assess means of population differences were mainly done using 
bioRxiv preprint doi: https://doi.org/10.1101/2022.03.07.483228; this version posted March 7, 2022. The copyright holder for this preprint (which was not certified by peer review) is the author/funder, who has granted bioRxiv a license to display the preprint in perpetuity. It is made available under aCC-BY 4.0 International license.

$805 t$-test whenever the variables could be assumed continuous, or otherwise using Wilcoxon Rank

806 Sum test, as indicated in the respective figure legends. Sample size estimations were not

807 performed in any of the experiments. All experiments were performed using at least $n=3$

808 biological replicates. Post-processing data analysis was conducted in R. Missing values in the

809 proteomics data were median imputed. Differential protein expression analysis was performed

810 using the limma package v3.48.3 in $\mathrm{R}{ }^{96}$. Gene Ontology (GO) terms were retrieved using

811 GO2ALLORFS object of org.Sc.sgd.db v3.14.0 package ${ }^{97}$ and enrichment analysis of

812 differentially expressed proteins was performed using hypergeometric statistical tests. GO slim

813 term mapper from SGD database ${ }^{98}$ was used to map differentially expressed proteins with GO

814 slim terms. KEGG term mapper from KEGG database ${ }^{99}$ used to map differentially expressed

815 proteins with KEGG terms. Metabolic enzyme expression levels were mapped to the yeast

816 metabolic network using iPATH3 ${ }^{100}$.

817

818 Data availability

819 The data supporting the findings of this study are available within the paper, its Supplementary

820 Information and will be deposited within publicly accessible repositories (before formal

821 acceptance). The proteomic datasets generated during the current study that are relevant to 822 data shown in Fig. 4 and Supplementary Fig 10-13 will be available from the PRoteomics

823 IDEntifications database (PRIDE, https://www.ebi.ac.uk/pride/) as part of the global

824 Proteomexchange (PX) consortium ${ }^{101}$. Yeast gene functions and GO slim term mapper can be

825 accessed at the Saccharomyces Genome Database (SGD, https://www.yeastgenome.org/).

826 Protein sequence databases used for the identification and mapping of proteins from proteomics

827 can be accessed via Uniprot (https://www.uniprot.org/) and KEGG

828 (https://www.genome.jp/kegg/pathway.html), respectively.

829

830 
bioRxiv preprint doi: https://doi.org/10.1101/2022.03.07.483228; this version posted March 7, 2022. The copyright holder for this preprint

(which was not certified by peer review) is the author/funder, who has granted bioRxiv a license to display the preprint in perpetuity. It is made available under aCC-BY 4.0 International license.

\section{Code availability}

832 No custom codes were generated as part of this study. All analyses conducted in R v3.6.1 used

833 standard, publicly accessible packages obtained either through GitHub (https://github.com/), the

834 Comprehensive R Archive Network (CRAN, https://cran.r-project.org/) or via Bioconductor

835 (https://www.bioconductor.org/).

836

837 Acknowledgements

838 We thank our lab member Dr. Benjamin Heineike (The Francis Crick Institute, London, UK) for 839 inspiring discussions. This work was supported by the Francis Crick Institute, which receives its 840 core funding from Cancer Research UK (FC001134), the UK Medical Research Council 841 (FC001134) and the Wellcome Trust (FC001134, IA 200829/Z/16/Z). This research was funded 842 in part by the Wellcome Trust (FC001134 and IA 200829/Z/16/Z to M.R., supporting C.C-M., 843 S.K., M.M. C.B.M., L.H-D., V.D., SJ.T., A.F., K.C., S.A., L.S. and J.S.L.Y). For the purpose of 844 Open Access, the author has applied a CC BY public copyright licence to any Author Accepted 845 Manuscript version arising from this submission. The work was further supported by the Ministry 846 of Education and Research (BMBF), as part of the National Research Node 'Mass spectrometry 847 in Systems Medicine (MSCoreSys)', under grant agreements 031L0220 (to M.R.) and 848 161L0221 (to V.D.), and the European Commission (EC) as part of CoBioTech project Sycolim 849 ID\#33. M.T.A. is funded by the United Arab Emirates University, Al Ain (UAE). The work 850 performed by R.T. is supported by the National Research, Development and Innovation Office 851 PD 128271 and B.P. is supported by the National Research, Development and Innovation 852 Office Élvonal Program KKP 129814, Lendület” program of the Hungarian Academy of 853 Sciences LP2009-013/2012 and the European Union's Horizon 2020 research and innovation 854 program Grant No. 739593. AZ was supported by the SciLifeLab funding and Marius Jason 855 Jakulis (MJJ) foundation. 
bioRxiv preprint doi: https://doi org/10.1101/2022 03.07 483228; this version posted March 7,2022 The copyright holder for this preprint (which was not certified by peer review) is the author/funder, who has granted bioRxiv a license to display the preprint in perpetuity. It is made available under aCC-BY 4.0 International license.

\section{Author contributions}

858 Conceptualization was carried out by C.C-M. and M.R. Methodology was the responsibility of

859 C.C-M., S.K., M.M., C.B.M, SJ.T and L.S. Experimental investigation and experimental design

860 was performed by C.C-M., S.K., M.M., L.H-D., C.B.M. R.T., A.F., K.C., B.P., S.A., L.S and

861 J.S.L.Y) Formal analysis was conducted by C.C-M., V.D., A.Z., SJ.T., and M.T.A. C.C-M and

862 M.R. wrote the article.

863

864 Conflict of interest

865 K.C. is currently employed by AstraZeneca. The authors declare no competing interests.

866

867

868 List of Supplementary Information

869 - Supplementary Figures: 1-13

870 - Supplementary Tables:1- 3

871 - Supplementary Files: 1-18 (provided as .xIxs or.csv)

872 


\section{References}

874 1. Zhu, J. \& Thompson, C. B. Metabolic regulation of cell growth and proliferation. Nat. Rev. 875 Mol. Cell Biol. 20, 436-450 (2019).

876 2. López-Otín, C., Galluzzi, L., Freije, J. M. P., Madeo, F. \& Kroemer, G. Metabolic Control of $877 \quad$ Longevity. Cell 166, 802-821 (2016).

878 3. Metallo, C. M. \& Vander Heiden, M. G. Understanding metabolic regulation and its 879 influence on cell physiology. Mol. Cell 49, 388-398 (2013).

880 4. Martínez, J. L. \& Rojo, F. Metabolic regulation of antibiotic resistance. FEMS Microbiol. $881 \quad$ Rev. 35, 768-789 (2011).

882 5. Ring, J. et al. The metabolism beyond programmed cell death in yeast. Exp. Cell Res. 318, $883 \quad 1193-1200(2012)$.

884 6. Moretton, A. \& Loizou, J. I. Interplay between Cellular Metabolism and the DNA Damage 885 Response in Cancer. Cancers 12, (2020).

7. Fontana, L. \& Partridge, L. Promoting health and longevity through diet: from model organisms to humans. Cell 161, 106-118 (2015).

888

8. Powers, R. W., 3rd, Kaeberlein, M., Caldwell, S. D., Kennedy, B. K. \& Fields, S. Extension of chronological life span in yeast by decreased TOR pathway signaling. Genes Dev. 20, 174-184 (2006).

9. Lu, J.-Y. et al. Acetylation of yeast AMPK controls intrinsic aging independently of caloric restriction. Cell 146, 969-979 (2011).

10. Kennedy, B. K., Austriaco, N. R., Jr, Zhang, J. \& Guarente, L. Mutation in the silencing gene SIR4 can delay aging in S. cerevisiae. Cell 80, 485-496 (1995).

11. Howitz, K. T. et al. Small molecule activators of sirtuins extend Saccharomyces cerevisiae lifespan. Nature 425, 191-196 (2003).

12. Bradshaw, P. C. Cytoplasmic and Mitochondrial NADPH-Coupled Redox Systems in the 898 Regulation of Aging. Nutrients 11, (2019). 
signalling agents. Nat. Rev. Mol. Cell Biol. 21, 363-383 (2020).

901 14. Piedrafita, G., Keller, M. A. \& Ralser, M. The impact of non-enzymatic reactions and 902 enzyme promiscuity on cellular metabolism during (oxidative) stress conditions.

$903 \quad$ Biomolecules 5, 2101-2122 (2015).

904 15. Correia-Melo, C., Hewitt, G. \& Passos, J. F. Telomeres, oxidative stress and inflammatory 905 factors: partners in cellular senescence? Longev Healthspan 3, 1 (2014).

906 16. Tan, B. L., Norhaizan, M. E., Liew, W.-P.-P. \& Sulaiman Rahman, H. Antioxidant and 907 Oxidative Stress: A Mutual Interplay in Age-Related Diseases. Front. Pharmacol. 9, 1162

908 (2018).

17. Balaban, R. S., Nemoto, S. \& Finkel, T. Mitochondria, oxidants, and aging. Cell 120, 483-

910 495 (2005).

911

18. Jang, C. et al. Metabolite Exchange between Mammalian Organs Quantified in Pigs. Cell Metab. 30, 594-606.e3 (2019).

19. Richter, F. C., Obba, S. \& Simon, A. K. Local exchange of metabolites shapes immunity. Immunology 155, 309-319 (2018).

20. Douglas, A. E. The microbial exometabolome: ecological resource and architect of microbial communities. Philos. Trans. R. Soc. Lond. B Biol. Sci. 375, 20190250 (2020).

21. D'Souza, G. et al. Ecology and evolution of metabolic cross-feeding interactions in bacteria. Nat. Prod. Rep. 35, 455-488 (2018).

22. Soeters, P. B. et al. The anabolic role of the Warburg, Cori-cycle and Crabtree effects in health and disease. Clin. Nutr. 40, 2988-2998 (2021).

23. Smith, P. \& Schuster, M. Public goods and cheating in microbes. Curr. Biol. 29, R442R447 (2019).

24. Frank, S. A. Microbial metabolism: optimal control of uptake versus synthesis. PeerJ 2, e267 (2014)

25. Paczia, N. et al. Extensive exometabolome analysis reveals extended overflow metabolism in various microorganisms. Microb. Cell Fact. 11, 122 (2012). 
927 26. Vazquez, A. \& Oltvai, Z. N. Macromolecular crowding explains overflow metabolism in cells.

928 Sci. Rep. 6, 31007 (2016).

929 27. Pinu, F. R. et al. Metabolite secretion in microorganisms: the theory of metabolic overflow $930 \quad$ put to the test. Metabolomics 14, 43 (2018).

931 28. Alam, M. T. et al. The self-inhibitory nature of metabolic networks and its alleviation through 932 compartmentalization. Nat. Commun. 8, 16018 (2017).

933 29. Kaleta, C., Schäuble, S., Rinas, U. \& Schuster, S. Metabolic costs of amino acid and protein production in Escherichia coli. Biotechnol. J. 8, 1105-1114 (2013).

30. D'Souza, G. et al. Less is more: selective advantages can explain the prevalent loss of biosynthetic genes in bacteria. Evolution 68, 2559-2570 (2014).

31. Wang, Y.-P. \& Lei, Q.-Y. Metabolite sensing and signaling in cell metabolism. Signal Transduct Target Ther 3, 30 (2018).

32. Campbell, K., Herrera-Dominguez, L., Correia-Melo, C., Zelezniak, A. \& Ralser, M. Biochemical principles enabling metabolic cooperativity and phenotypic heterogeneity at the single cell level. Current Opinion in Systems Biology 8, 97-108 (2018).

33. Conrad, M. et al. Nutrient sensing and signaling in the yeast Saccharomyces cerevisiae. FEMS Microbiol. Rev. 38, 254-299 (2014).

34. Goyal, S., Yuan, J., Chen, T., Rabinowitz, J. D. \& Wingreen, N. S. Achieving optimal growth through product feedback inhibition in metabolism. PLoS Comput. Biol. 6, e1000802 (2010).

35. Evans, C. R., Kempes, C. P., Price-Whelan, A. \& Dietrich, L. E. P. Metabolic Heterogeneity and Cross-Feeding in Bacterial Multicellular Systems. Trends Microbiol. 28, 732-743 (2020).

36. Campbell, K., Vowinckel, J. \& Ralser, M. Cell-to-cell heterogeneity emerges as consequence of metabolic cooperation in a synthetic yeast community. Biotechnol. J. 11, 1169-1178 (2016). 

available under aCC-BY 4.0 International license.

underground polyamine metabolism. Nature 572, 249-253 (2019).

955

956

957

958

959

960

961

962

963

964

965

966

967

968

969

970

971

972

973

974

975

976

977

978

979

980

38. $\mathrm{Yu}, \mathrm{J}$. et al. Microbial communities form rich extracellular metabolomes that foster metabolic interactions and promote drug tolerance. Nature Microbiology (2022, in press) doi:10.1038/s41564-022-01072-5.

39. MacLean, M., Harris, N. \& Piper, P. W. Chronological lifespan of stationary phase yeast cells; a model for investigating the factors that might influence the ageing of postmitotic tissues in higher organisms. Yeast 18, 499-509 (2001).

40. Laun, P., Rinnerthaler, M., Bogengruber, E., Heeren, G. \& Breitenbach, M. Yeast as a model for chronological and reproductive aging - a comparison. Exp. Gerontol. 41, 12081212 (2006).

41. Campbell, K. et al. Self-establishing communities enable cooperative metabolite exchange in a eukaryote. Elife 4, (2015).

42. Brachmann, C. B. et al. Designer deletion strains derived from Saccharomyces cerevisiae S288C: a useful set of strains and plasmids for PCR-mediated gene disruption and other applications. Yeast 14, 115-132 (1998).

43. Kamrad, S. et al. Pyruvate kinase variant of fission yeast tunes carbon metabolism, cell regulation, growth and stress resistance. Mol. Syst. Biol. 16, e9270 (2020).

44. Galdieri, L., Mehrotra, S., Yu, S. \& Vancura, A. Transcriptional regulation in yeast during diauxic shift and stationary phase. OMICS 14, 629-638 (2010).

45. Slavov, N. \& Botstein, D. Coupling among growth rate response, metabolic cycle, and cell division cycle in yeast. Mol. Biol. Cell 22, 1997-2009 (2011).

46. Zampar, G. G. et al. Temporal system-level organization of the switch from glycolytic to gluconeogenic operation in yeast. Mol. Syst. Biol. 9, 651 (2013).

47. Bianchi, F., van't Klooster, J. S., Ruiz, S. J. \& Poolman, B. Regulation of Amino Acid Transport in Saccharomyces cerevisiae. Microbiol. Mol. Biol. Rev. 83, (2019).

48. Kumar, K., Venkatraman, V. \& Bruheim, P. Adaptation of central metabolite pools to variations in growth rate and cultivation conditions in Saccharomyces cerevisiae. Microb. 
bioRxiv preprint doi: https://doi.org/10.1101/2022.03.07.483228; this version posted March 7, 2022. The copyright holder for this preprint (which was not certified by peer review) is the author/funder, who has granted bioRxiv a license to display the preprint in perpetuity. It is made available under aCC-BY 4.0 International license.

$981 \quad$ Cell Fact. 20, 64 (2021).

982 49. Ponomarova, O. et al. Yeast Creates a Niche for Symbiotic Lactic Acid Bacteria through $983 \quad$ Nitrogen Overflow. Cell Syst 5, 345-357.e6 (2017).

984 50. Mülleder, M., Bluemlein, K. \& Ralser, M. A High-Throughput Method for the Quantitative 985 Determination of Free Amino Acids in Saccharomyces cerevisiae by Hydrophilic Interaction 986 Chromatography-Tandem Mass Spectrometry. Cold Spring Harb. Protoc. 2017, 987 db.prot089094 (2017).

988

51. Campbell, K., Correia-Melo, C. \& Ralser, M. Self-Establishing Communities: A Yeast Model to Study the Physiological Impact of Metabolic Cooperation in Eukaryotic Cells. Methods Mol. Biol. 2049, 263-282 (2019).

52. Burtner, C. R., Murakami, C. J., Kennedy, B. K. \& Kaeberlein, M. A molecular mechanism of chronological aging in yeast. Cell Cycle 8, 1256-1270 (2009).

53. Piper, M. D. W., Partridge, L., Raubenheimer, D. \& Simpson, S. J. Dietary restriction and aging: a unifying perspective. Cell Metab. 14, 154-160 (2011).

54. Alam, M. T. et al. The metabolic background is a global player in Saccharomyces gene expression epistasis. Nat Microbiol 1, 15030 (2016).

55. Bárcena, C. et al. Methionine Restriction Extends Lifespan in Progeroid Mice and Alters Lipid and Bile Acid Metabolism. Cell Rep. 24, 2392-2403 (2018).

56. Lee, B. C. et al. Methionine restriction extends lifespan of Drosophila melanogaster under conditions of low amino-acid status. Nat. Commun. 5, 3592 (2014).

57. Plummer, J. D. \& Johnson, J. E. Extension of Cellular Lifespan by Methionine Restriction Involves Alterations in Central Carbon Metabolism and Is Mitophagy-Dependent. Front Cell Dev Biol 7, 301 (2019).

1004

58. Brind, J. et al. Dietary glycine supplementation mimics lifespan extension by dietary methionine restriction in Fisher 344 rats. The FASEB Journal 25, 528.2-528.2 (2011). dependent vacuolar acidification. PLoS Genet. 10, e1004347 (2014). 
1008 60. Orentreich, N., Matias, J. R., DeFelice, A. \& Zimmerman, J. A. Low methionine ingestion by 1009 rats extends life span. J. Nutr. 123, 269-274 (1993).

1010 61. Vowinckel, J. et al. Cost-effective generation of precise label-free quantitative proteomes in 1011 high-throughput by microLC and data-independent acquisition. Sci. Rep. 8, 4346 (2018).

1012 62. Demichev, V., Messner, C. B., Vernardis, S. I., Lilley, K. S. \& Ralser, M. DIA-NN: neural 1013 networks and interference correction enable deep proteome coverage in high throughput. $1014 \quad$ Nat. Methods 17, 41-44 (2020).

1015 63. Ghaemmaghami, S. et al. Global analysis of protein expression in yeast. Nature 425, 737$1016741(2003)$.

1017 64. Väremo, L., Nielsen, J. \& Nookaew, I. Enriching the gene set analysis of genome-wide data 1018 by incorporating directionality of gene expression and combining statistical hypotheses and methods. Nucleic Acids Res. 41, 4378-4391 (2013).

65. Lin, S.-J. et al. Calorie restriction extends Saccharomyces cerevisiae lifespan by increasing respiration. Nature 418, 344-348 (2002).

66. Orlandi, I., Ronzulli, R., Casatta, N. \& Vai, M. Ethanol and acetate acting as carbon/energy sources negatively affect yeast chronological aging. Oxid. Med. Cell. Longev. 2013, 802870 (2013).

67. Wei, M. et al. Tor1/Sch9-regulated carbon source substitution is as effective as calorie restriction in life span extension. PLoS Genet. 5, e1000467 (2009).

68. Shafer, M. E. R. Cross-Species Analysis of Single-Cell Transcriptomic Data. Front Cell Dev Biol 7, 175 (2019).

69. Evers, T. M. J. et al. Deciphering Metabolic Heterogeneity by Single-Cell Analysis. Anal. Chem. 91, 13314-13323 (2019).

70. Xiao, Z., Dai, Z. \& Locasale, J. W. Metabolic landscape of the tumor microenvironment at single cell resolution. Nat. Commun. 10, 3763 (2019).

71. Zelezniak, A. et al. Metabolic dependencies drive species co-occurrence in diverse microbial communities. Proc. Natl. Acad. Sci. U. S. A. 112, 6449-6454 (2015). 
1035 72. Kouzuma, A., Kato, S. \& Watanabe, K. Microbial interspecies interactions: recent findings in 1036 syntrophic consortia. Front. Microbiol. 6, 477 (2015).

1037 73. Kundu, P., Manna, B., Majumder, S. \& Ghosh, A. Species-wide Metabolic Interaction $1038 \quad$ Network for Understanding Natural Lignocellulose Digestion in Termite Gut Microbiota. Sci. 1039 Rep. 9, 16329 (2019).

1040 74. Zengler, K. \& Zaramela, L. S. The social network of microorganisms - how auxotrophies shape complex communities. Nat. Rev. Microbiol. 16, 383-390 (2018).

1042 75. Thompson, L. R. et al. A communal catalogue reveals Earth's multiscale microbial diversity. Nature 551, 457-463 (2017).

1044 76. Váchová, L. \& Palková, Z. Aging and longevity of yeast colony populations: metabolic adaptation and differentiation. Biochem. Soc. Trans. 39, 1471-1475 (2011).

77. Brosnan, J. T. \& Brosnan, M. E. The sulfur-containing amino acids: an overview. J. Nutr. 136, 1636S-1640S (2006).

78. Dong, Z., Sinha, R. \& Richie, J. P., Jr. Disease prevention and delayed aging by dietary sulfur amino acid restriction: translational implications. Ann. N. Y. Acad. Sci. 1418, 44-55 (2018).

79. Sanderson, S. M., Gao, X., Dai, Z. \& Locasale, J. W. Methionine metabolism in health and cancer: a nexus of diet and precision medicine. Nat. Rev. Cancer 19, 625-637 (2019).

80. Gao, X. et al. Dietary methionine influences therapy in mouse cancer models and alters human metabolism. Nature 572, 397-401 (2019).

81. Udom, N., Chansongkrow, P., Charoensawan, V. \& Auesukaree, C. Coordination of the Cell Wall Integrity and High-Osmolarity Glycerol Pathways in Response to Ethanol Stress in Saccharomyces cerevisiae. Appl. Environ. Microbiol. 85, (2019).

1059

82. Aman, Y. et al. Autophagy in healthy aging and disease. Nat Aging 1, 634-650 (2021).

1060

83. Moger-Reischer, R. Z. \& Lennon, J. T. Microbial ageing and longevity. Nat. Rev. Microbiol. 17, 679-690 (2019). 
cerevisiae. Microbiol. Mol. Biol. Rev. 61, 503-532 (1997).

1063 85. Mülleder, M., Campbell, K., Matsarskaia, O., Eckerstorfer, F. \& Ralser, M. Saccharomyces 1064 cerevisiae single-copy plasmids for auxotrophy compensation, multiple marker selection, 1065 and for designing metabolically cooperating communities. F1000Res. 5, 2351 (2016).

1066 86. Gietz, R. D. \& Schiestl, R. H. High-efficiency Yeast Transformation Using the LiAc/SS 1067 Carrier DNA/PEG Method. Nat. Protoc. 2, (2007).

1068

1069

1070

1071

1072

1073

1074

1075

1076

1077

1078

1079

1080

1081

1082

1083

1084

1085

1086

1087

1088

87. Sprouffske, K. \& Wagner, A. Growthcurver: an R package for obtaining interpretable metrics from microbial growth curves. BMC Bioinformatics 17, 172 (2016).

88. Longo, V. D., Shadel, G. S., Kaeberlein, M. \& Kennedy, B. Replicative and chronological aging in Saccharomyces cerevisiae. Cell Metab. 16, 18-31 (2012).

89. Romila, C. A. et al. Barcode Sequencing and a High-throughput Assay for Chronological Lifespan Uncover Ageing-associated Genes in Fission Yeast. Cold Spring Harbor Laboratory 2021.03.04.433786 (2021) doi:10.1101/2021.03.04.433786.

90. Kamrad, S. et al. Pyphe, a python toolbox for assessing microbial growth and cell viability in high-throughput colony screens. Elife 9, (2020).

91. Bligh, E. G. \& Dyer, W. J. A rapid method of total lipid extraction and purification. Can. J. Biochem. Physiol. 37, 911-917 (1959).

92. R Core Team. R: A language and environment for statistical computing. (R Foundation for Statistical Computing, 2015).

93. Mo, M. L., Palsson, B. Ø. \& Herrgård, M. J. Connecting extracellular metabolomic measurements to intracellular flux states in yeast. BMC Syst. Biol. 3, 37 (2009).

94. Szappanos, B. et al. An integrated approach to characterize genetic interaction networks in yeast metabolism. Nat. Genet. 43, (2011).

95. Heirendt, L. et al. Creation and analysis of biochemical constraint-based models using the COBRA Toolbox v.3.0. Nat. Protoc. 14, 639-702 (2019).

96. Ritchie, M. E. et al. limma powers differential expression analyses for RNA-sequencing and microarray studies. Nucleic Acids Res. 43, e47 (2015). 
bioRxiv preprint doi: https://doi.org/10.1101/2022 03.07.483228; this version posted March 7, 2022. The copyright holder for this preprint (which was not certified by peer review) is the author/funder, who has granted bioRxiv a license to display the preprint in perpetuity. It is made available under aCC-BY 4.0 International license.

1089 97. Carlson, M. org.Sc.sgd.db: Genome wide annotation for Yeast. $R$ package version 3.8.2.

$1090 \quad$ (2019).

1091 98. Cherry, J. M. et al. Saccharomyces Genome Database: the genomics resource of budding

1092 yeast. Nucleic Acids Res. 40, D700-5 (2012).

1093 99. Kanehisa, M., Sato, Y., Kawashima, M., Furumichi, M. \& Tanabe, M. KEGG as a reference

1094 resource for gene and protein annotation. Nucleic Acids Res. 44, D457-62 (2016).

1095 100.Darzi, Y., Letunic, I., Bork, P. \& Yamada, T. iPath3.0: interactive pathways explorer v3.

$1096 \quad$ Nucleic Acids Res. 46, W510-W513 (2018).

1097 101.Perez-Riverol, Y. et al. The PRIDE database and related tools and resources in 2019:

1098 improving support for quantification data. Nucleic Acids Res. 47, D442-D450 (2019). 
bioRxiv preprint doi: https://doi.org/10.1101/2022.03.07.483228; this version posted March 7, 2022. The copyright holder for this preprint (which was not certified by peer review) is the author/funder, who has granted bioRxiv a license to display the preprint in perpetuity. It is made available under aCC-BY 4.0 International license.

\section{Figures}

a

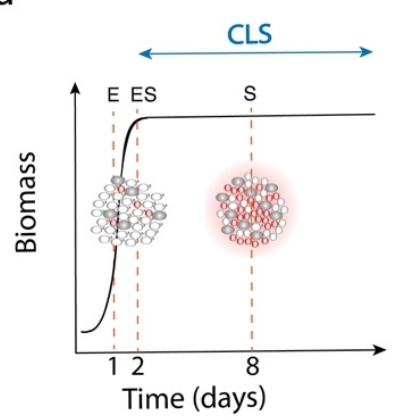

C

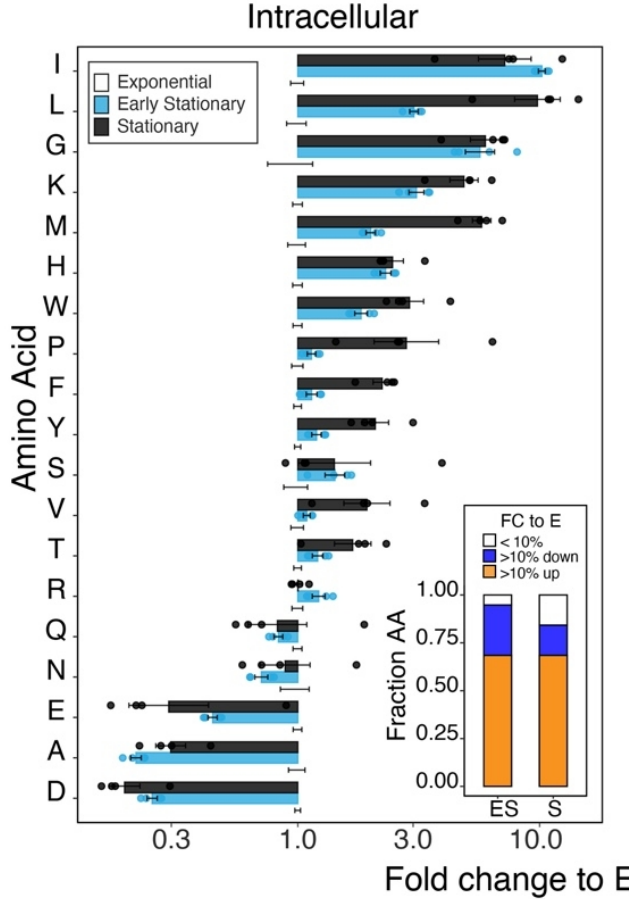

b

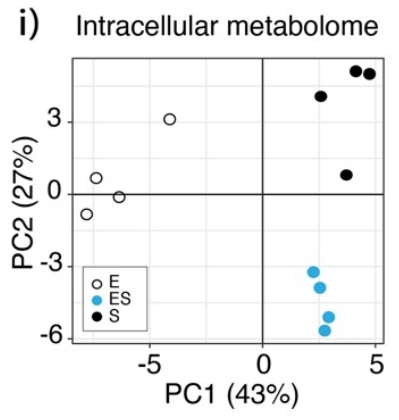

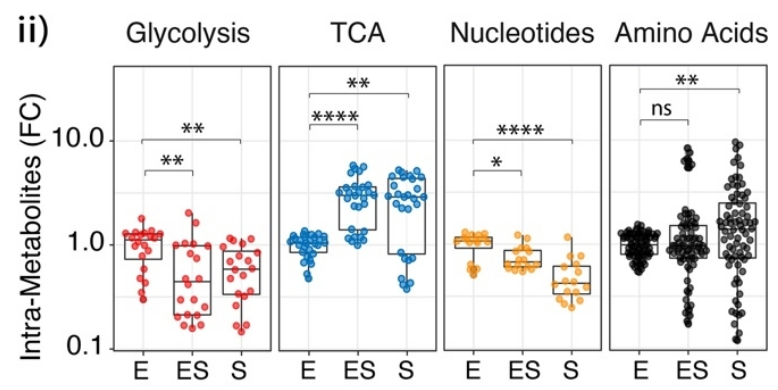

d
Extracellular

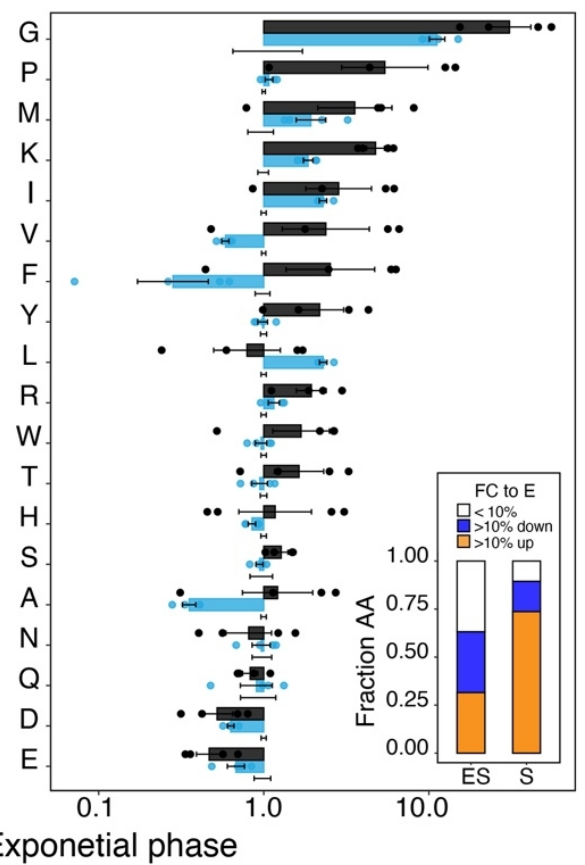

Metabolite exchange

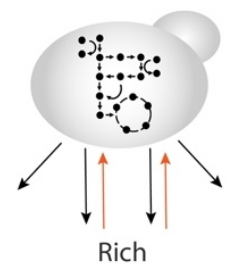

Exometabolome
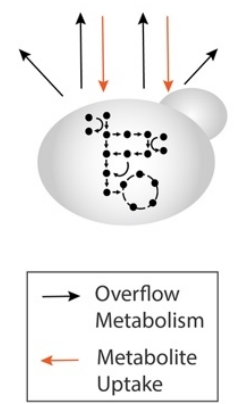

e

i)

Pre-swap Post-swap

Culture time (h):

$\mathrm{SM}+$

12C-Glucose

$\mathrm{SM}+$

13C-Glucose

$\mathrm{SM}+$

13C-Glucose

Sampling time (h):

*pre-swap
$48>72$

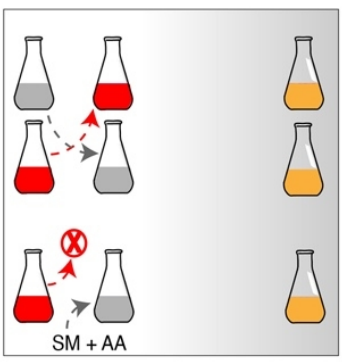

$\begin{array}{llllll}0 * & 2 & 6 & 24 & 48 & 72\end{array}$ Stationary phase ii)

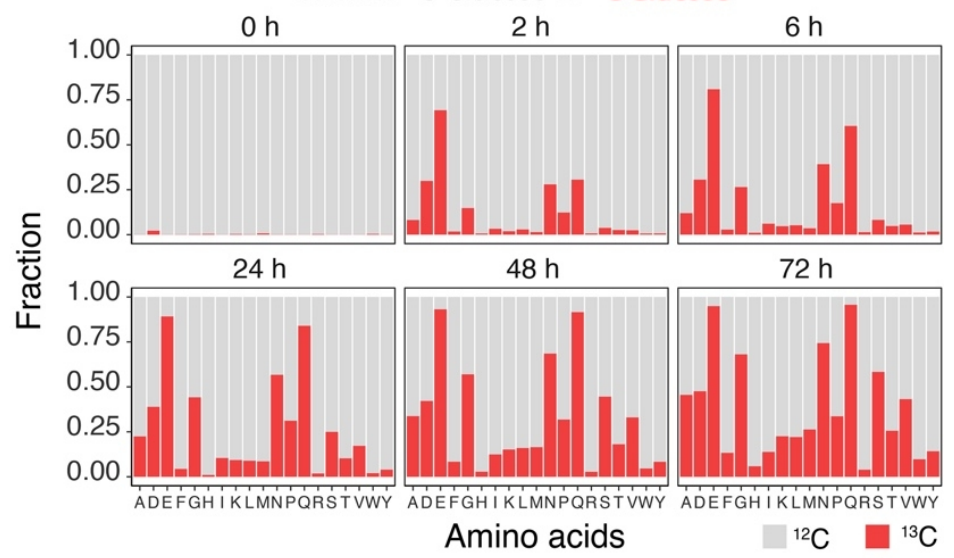


bioRxiv preprint doi: https://doi.org/10.1101/2022.03.07.483228; this version posted March 7, 2022. The copyright holder for this preprint (which was not certified by peer review) is the author/funder, who has granted bioRxiv a license to display the preprint in perpetuity. It is made available under aCC-BY 4.0 International license.

1102 Figure 1. Metabolites exported by exponentially growing yeast cells are imported by

1103 chronologically ageing cells in the stationary phase. a) Scheme: Growth phases of yeast in batch

1104 culture, and the measurement of chronological lifespan (CLS) as survival in the stationary phase. (E)

1105 exponential growth phase, (ES) early stationary phase and (S) stationary phase. Red dotted lines indicate

1106 the time points of sample collection for metabolomic analysis (1,2 and 8 days from culture start,

1107 indicating E, ES and S phases). b) Targeted intracellular metabolome (intra-metabolome) analysis for the

1108 quantification of nucleotides, amino acids, glycolysis and tricarboxylic acid cycle (TCA) metabolites, in

1109 wild-type yeast cells cultured in synthetic minimal (SM) medium at 1 (E), 2 (ES) and 8 (S) days from

1110 culture start, respectively. i) Principal component analysis (PCA) reflects metabolomic differences

1111 between E, ES and $S$ growth phases. Data are $n=4$ independent cultures (individual dots represent

1112 independent cultures). ii) Intracellular metabolite concentrations shown as fold change (FC to exponential

1113 phase) of different metabolites according to metabolite classes in the different growth phases.

1114 Concentration of each metabolite was first normalised by biomass, as assessed by $\mathrm{OD}_{600}$. Box plots

1115 represent median ( $50 \%$ quantile, middle line) and lower and upper quantiles (lower ( $25 \%$ quantile) and

1116 upper (75\% quantile), respectively) of pooled metabolite levels of 4 independent cultures. Each dot

1117 represents a metabolite in a biological replicate. Statistics by unpaired two-sided Wilcoxon Rank Sum test

1118 and multiple testing correction using the $\mathrm{BH}$ method; adjusted p-values ${ }^{*}<0.05,{ }^{* *}<0.005,{ }^{* * *}<0.0005$ and

$1119^{* * * *}<0.00005$; adjusted p-values are listed in Supplementary File 1. c) Intracellular and extracellular

1120 amino acids levels in wild-type cultures during exponential (E), early stationary (ES) and stationary (S)

1121 phases. Bar plots show mean \pm SEM fold change ( $F C$ to levels in the exponential phase) of $n=4$

1122 independent wild-type yeast cultures. Statistics by unpaired two-sided Wilcoxon Rank Sum test and

1123 multiple testing correction using the $\mathrm{BH}$ method; adjusted p-values are listed in Supplementary File 2.

1124 Inlets represent the fraction of amino acids (from a total of 19) that show minimal changes, are decreased

1125 or increased in the $\mathrm{FC}$ to exponential phase $(\mathrm{E})$, as shown by $\mathrm{FC}<10 \%, \mathrm{FC}>10 \%$ down and $\mathrm{FC}>10 \%$ up,

1126 respectively. d) Scheme: Cells synthesise metabolites, following the stoichiometric rules of the metabolic

1127 network, wherein some metabolites are exported in order to maintain metabolic homeostasis (overflow

1128 metabolism), contributing to the metabolic enrichment of the extracellular environment (rich-

1129 exometabolome). At the same time, cells can sense and import metabolites from the surrounding

1130 environment. These dynamic export/import properties result in the exchange of metabolites between co-

1131 growing cells and the establishment of intercellular metabolic interactions. e) i) Scheme: Isotope tracing 
bioRxiv preprint doi: https://doi.org/10.1101/2022 03.07.483228; this version posted March 7,2022. The copyright holder for this preprint (which was not certified by peer review) is the author/funder, who has granted bioRxiv a license to display the preprint in perpetuity. It is made available under ACC-BY 4.0 International license.

1132 experimental design. Prototrophic yeast cells were grown in SM media supplemented either with ${ }^{12} \mathrm{C}$ -

1133 glucose or ${ }^{13} \mathrm{C}$-glucose, during 48 hours, then the media was swapped for isotope tracing amino acid

1134 analysis using targeted metabolomics by HPLC-MS/MS ${ }^{50}$, at 2, 6, 24, 48 and 72 hours post media swap

1135 (plus a control $0 \mathrm{~h}$ collection, just prior swapping media). Control cultures were swapped from SM

1136 supplemented with ${ }^{13} \mathrm{C}$-glucose to $\mathrm{SM}$ solely supplemented with ${ }^{12} \mathrm{C}$-amino acids (AA) at standard

1137 culturing concentrations (see Methods). ii) Fractions of ${ }^{12} \mathrm{C}$ and ${ }^{13} \mathrm{C}$ labelled amino acids in cultures

1138 initially grown in $\mathrm{SM}+{ }^{12} \mathrm{C}$-glucose and swapped to ${ }^{13} \mathrm{C}$-glucose, at different time points post media swap,

1139 as described in i). Data represents the mean of 4 independent cultures; Individual fraction values are

1140 listed in Supplementary File 3.

1141 
bioRxiv preprint doi: https://doi.org/10.1101/2022.03.07.483228; this version posted March 7. 2022. The copyright holder for this preprint (which was not certified by peer review) is the author/funder, who has granted bioRxiv a license to display the preprint in perpetuity. It is made available under aCC-BY 4.0 International license.

a

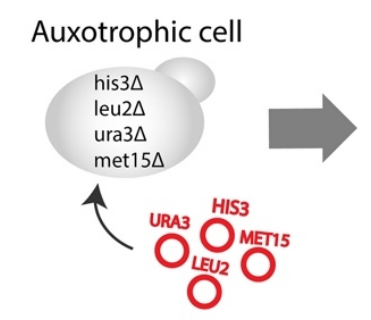

Prototrophic cell

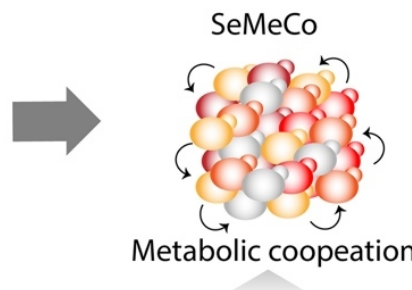

SeMeCo

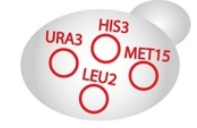

Proliferation \&

Metabolic coopeation

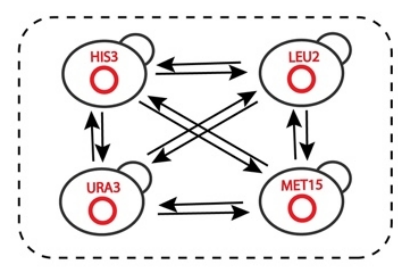

plasmid loss

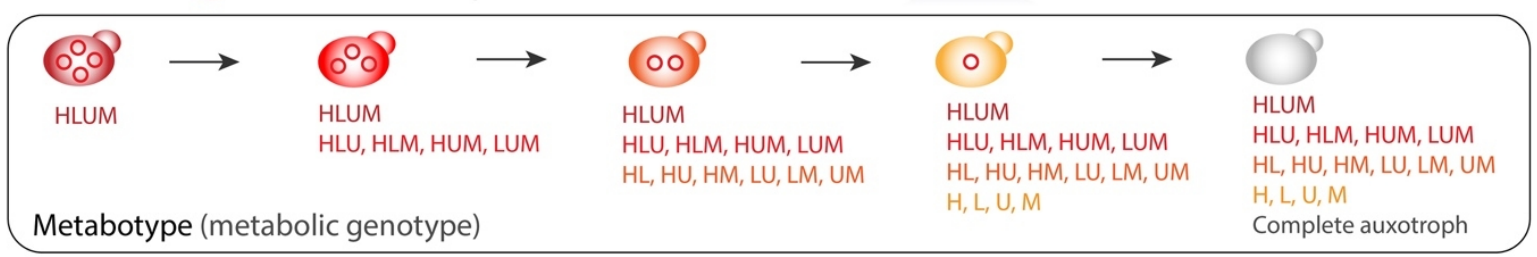

b

SeMeCo generation Pre-Culture Chronologic Lifespan culture
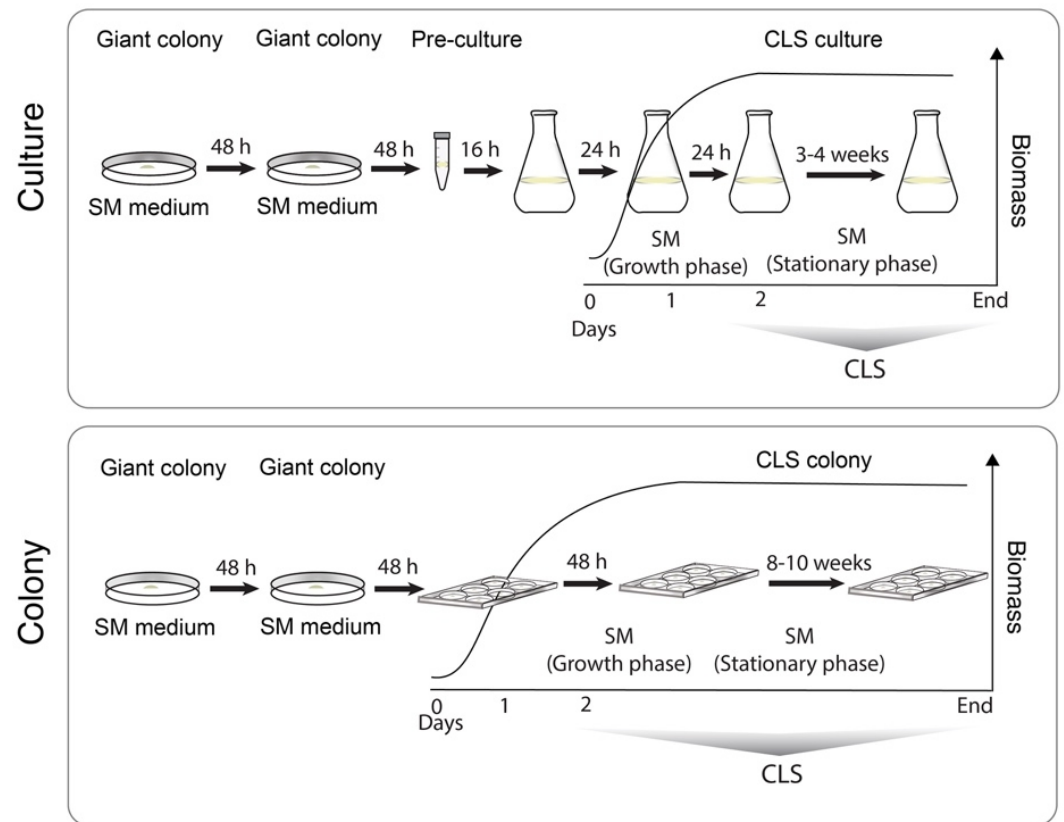

C
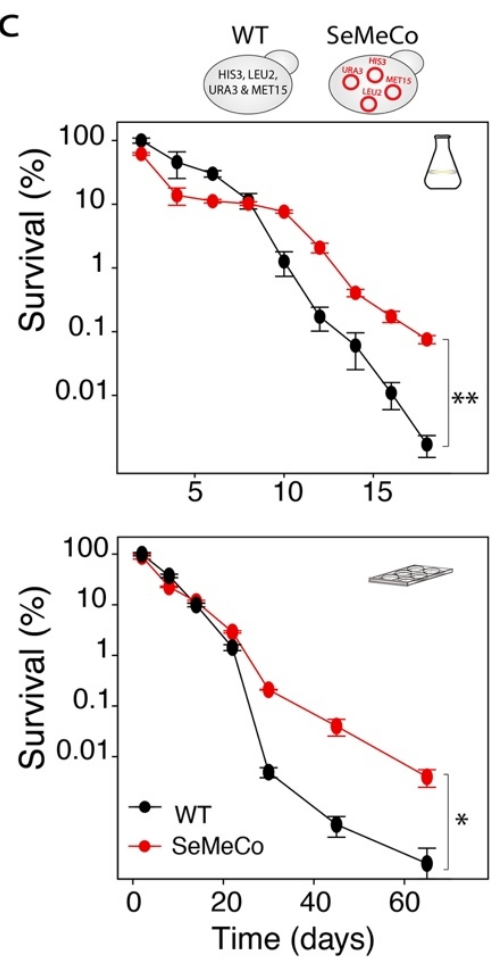

d

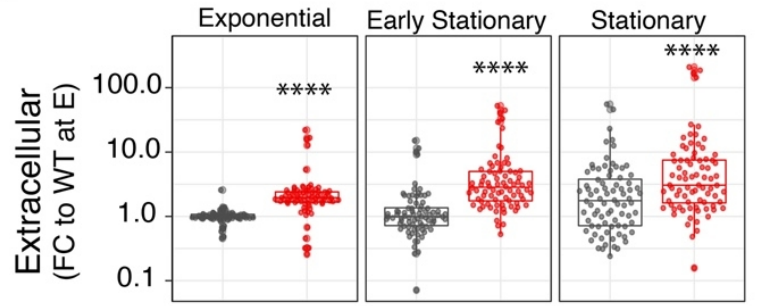

审 WT 审 SeMeCo
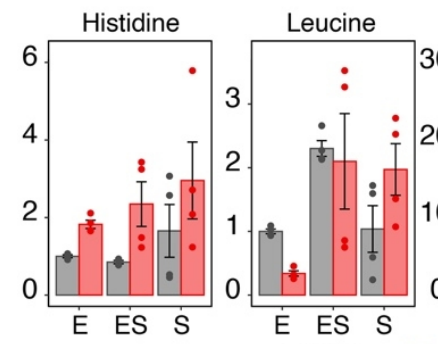

ค WT

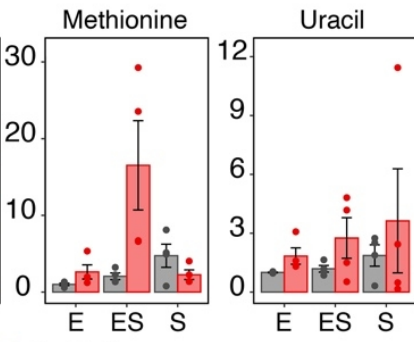

SeMeCo

1145 Figure 2. Boosting Metabolite exchange interactions extends chronological lifespan a) Scheme:

1146 Self-establishing metabolically cooperating communities (SeMeCos) maximise metabolite exchange 
bioRxiv preprint doi: https://doi.org/10.1101/2022.03.07.483228; this version posted March 7, 2022. The copyright holder for this preprint (which was not certified by peer review) is the author/funder, who has granted bioRxiv a license to display the preprint in perpetuity. It is made available under aCC-BY 4.0 International license.

1147 interactions through the segregation of plasmid-encoded auxotrophic markers. The SeMeCo system

1148 starts with a prototrophic cell that carries four essential metabolic markers on centromeric metastable 1149 plasmids ( $\mathrm{pHIS3}, \mathrm{pLEU2}$, pMET15 and $p U R A 3$ ) instead of stable integration in the genome (prototrophic 1150 wild-type). When these cells grow into a community, the stochastic plasmid segregation leads to an 1151 increasing number of auxotrophs that continue to proliferate on the basis of metabolites produced by 1152 other cells. Segregation continues until a maximum number of auxotrophs that the community can 1153 maintain is reached. Sixteen different metabotypes (metabolic genotypes) can arise from the differential 1154 segregation of the four metabolic markers. b) Chronological lifespan (CLS) of wild-type and SeMeCo 1155 communities grown in liquid SM media cultures, start by spotting giant colonies twice to ensure cell 1156 proliferation, plasmid segregation and ultimately cross-feeding between auxotrophs and prototrophs 1157 (SeMeCos generation), followed by pre-culture and culture, set at high cellular density (assessed by $1158 \mathrm{OD}_{600}$ ) to minimally disturb the composition of SeMeCos in conditions of unsupplemented media. (bottom)

1159 CLS of cells grown in a colony follow the same initial SeMeCo generation before re-spotting giant 1160 colonies into 6-well plates containing solid SM media. Samples are collected at different time points for 1161 survival assessment. c) (top) Culture and (bottom) colony CLS analysis assessing survival of wild-type 1162 and SeMeCos. Survival was evaluated using colony forming units (CFU) analysis, normalised to biomass 1163 (see Methods). Data are mean \pm SEM survival (percentage fold change) compared to wild-type mean 1164 survival at the beginning of stationary phase ( $48 \mathrm{~h}$ culture); $\mathrm{n}=4$ independent cultures per strain (Culture 1165 CLS) or $n=3$ independent colonies per strain (Colony CLS). Statistics using unpaired two-sided $t$-test, $\mathrm{p}$ 1166 value $=0.00661$ at day 18 of culture and $p$-value $=0.0338$ at day 65 in the colony; $p$-values across CLSs

1167 are listed in Supplementary File 4. d) Extracellular amino acids and uracil levels, measured by HPLC$1168 \mathrm{MS} / \mathrm{MS}^{50}$, in wild-type and SeMeCos cultures during exponential (E), early stationary (ES) and stationary 1169 (S) phases. Data are individual metabolite fold-change (FC to mean wild-type levels in the exponential 1170 phase) of $n=4$ independent cultures per strain. Data comparing wild-type values from Fig 1c; samples 1171 were cultured, extracted and measured in parallel. Concentration of each metabolite was first normalised 1172 to biomass, as assessed by $\mathrm{OD}_{600}$. (left) Box plots showing overall metabolite $\mathrm{FC}$ distribution over time; 1173 box plots represent median ( $50 \%$ quantile, middle line) and lower and upper quantiles (lower (25\% 1174 quantile) and upper (75\% quantile). (right) Bar plots show the mean \pm SEM FC of the shared metabolites 1175 (HLUM) in SeMeCos over time. Statistics by unpaired two-sided Wilcoxon Rank Sum test and multiple 
bioRxiv preprint doi: https://doi.org/10.1101/2022.03.07.483228; this version posted March 7, 2022. The copyright holder for this preprint (which was not certified by peer review) is the author/funder, who has granted bioRxiv a license to display the preprint in perpetuity. It is made available under aCC-BY 4.0 International license.

1176 testing correction using the $\mathrm{BH}$ method; adjusted p-value ${ }^{*}<0.05,{ }^{* *}<0.005,{ }^{* * *}<0.0005$ and ${ }^{* * * *}<0.00005$;

1177 adjusted p-values are listed in Supplementary File 6.

1178 
bioRxiv preprint doi: https://doi.org/10.1101/2022.03.07.483228; this version posted March 7. 2022. The copyright holder for this preprint (which was not certified by peer review) is the author/funder, who has granted bioRxiv a license to display the preprint in perpetuity. It is made available under aCC-BY 4.0 International license.

a

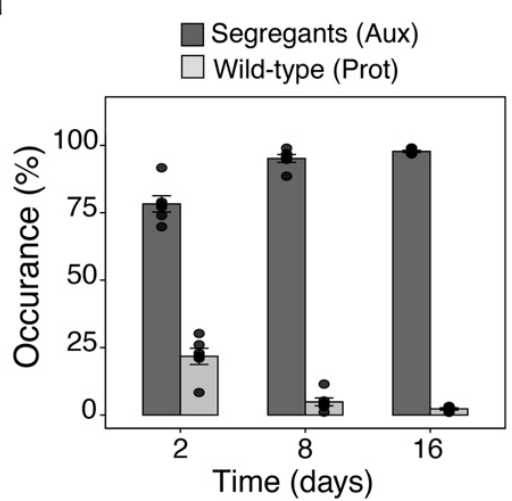

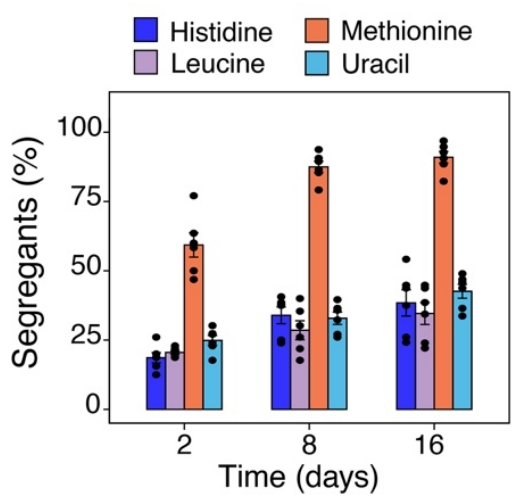

b

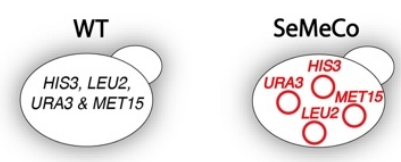

$3 p-S e M e C o$

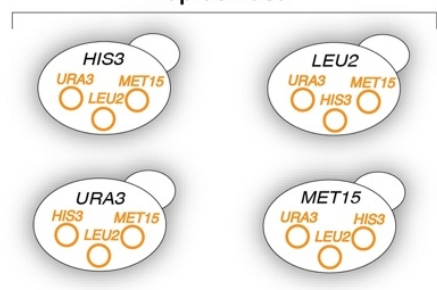

C

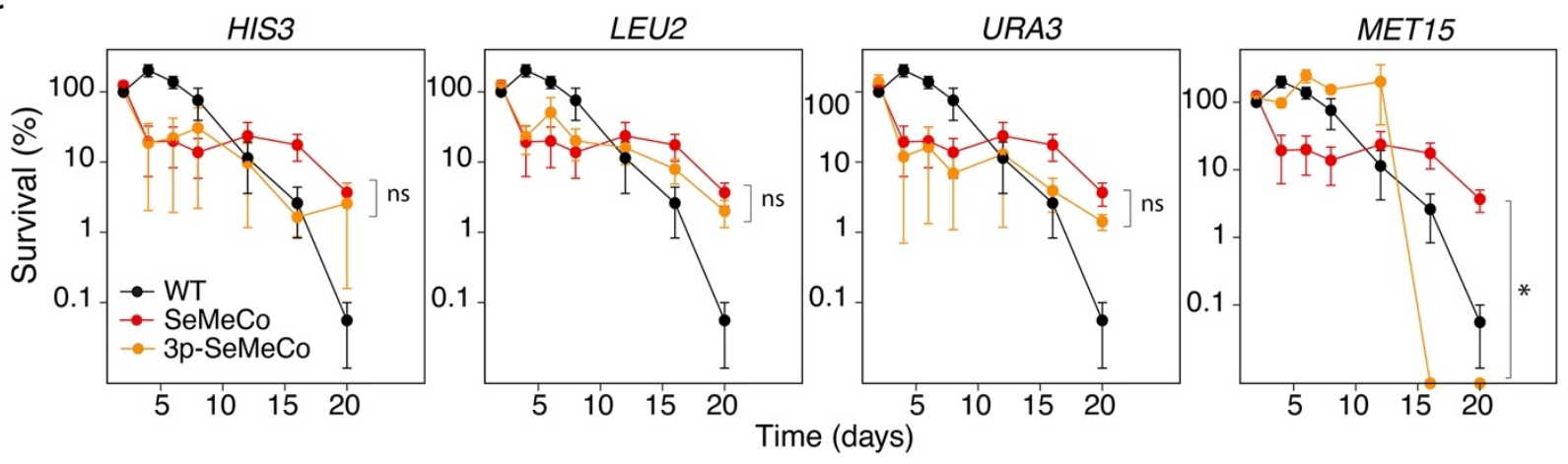

d

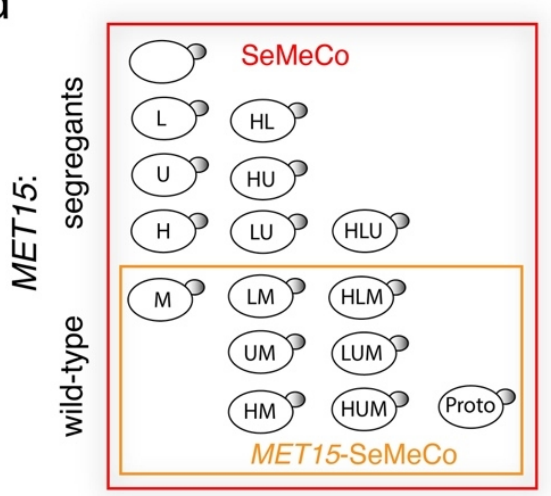

e

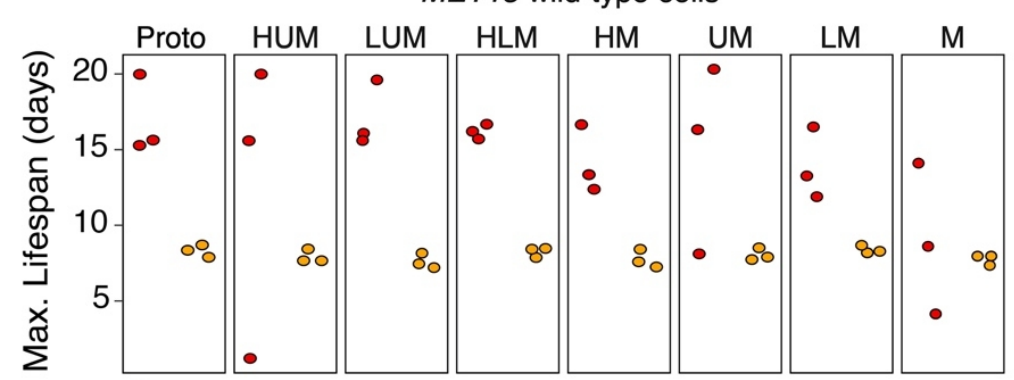

- SeMeCo: in the presence of MET15 segregants

- MET15-SeMeCo: in the absense of MET15 segregants

Figure 3. Metabolic interactions between MET15 and $\triangle$ met15 cells promote a paracrine lifespan auxotrophy for $\mathrm{H}, \mathrm{L}, \mathrm{U}$ and/or $\mathrm{M}$ ) and genetically prototrophic (bearing the four wild-type locus) cells during CLS. (right) Frequency of the individual segregants, i.e. per auxotrophy for $\mathrm{H}, \mathrm{L}, \mathrm{U}$ or $\mathrm{M}$ over time. Bar plots show the mean \pm SEM of $n=6$ independent SeMeCo cultures across 2 independent experiments (dots represent independent cultures). Statistics by paired two-sided $t$-test; $p$-values listed in 
bioRxiv preprint doi: https://doi.org/10.1101/2022.03.07.483228; this version posted March 7, 2022. The copyright holder for this preprint (which was not certified by peer review) is the author/funder, who has granted bioRxiv a license to display the preprint in perpetuity. It is made available under aCC-BY 4.0 International license.

1189 the most abundant metabotype during CLS. b) Schematics: Wild-type, SeMeCos and four '3p-SeMeCos',

1190 in which one of the markers (HIS3, LEU2, MET15 or URA3) is genomically integrated and does no longer

1191 segregate. c) Survival percentage of wild-type, SeMeCos and 3p-SeMeCos during CLS (assessed by

1192 high-throughput CFU (HTP-CFU) normalised per biomass). Data are mean \pm SEM survival (percentage

1193 fold change) compared to wild-type mean survival at the beginning of stationary phase (48h culture); $\mathrm{n}=4$

1194 independent cultures per strain. Survival curves are shown separately for each $3 p-S e M e C o s$ for

1195 visualisation purposes (all strains were cultured and analysed in parallel). Statistics by unpaired two-sided

1196 Wilcoxon Rank Sum test; p-value at day 20 of culture for: SeMeCo vs wt $=0.0294$ SeMeCo vs HIS3-

1197 SeMeCo $=0.3428$, SeMeCo vs LEU2-SeMeCo $=0.3428$, SeMeCo vs URA3-SeMeCo $=0.2000$, SeMeCo

1198 vs MET15-SeMeCo $=0.0210 ; p$-values across CLSs are listed in Supplementary File 8. d) The

1199 segregation of the four metabolic markers gives rise to 16 different metabotypes, eight of which have

1200 segregated the MET15 plasmid (Fig. 2a). e) Maximum lifespan of the eight MET15 wild-type

1201 metabotypes, in the presence (SeMeCo, red) or absence (MET15-SeMeCo, yellow) of MET15

1202 segregants. Dots are independent cultures per SeMeco type. Data are from n=3 independent cultures per

1203 SeMeCo. Statistics by unpaired one-sided Wilcoxon Rank Sum test; p-values in Supplementary File 11. 
bioRxiv preprint doi: https://doi.org/10.1101/2022.03.07.483228; this version posted March 7, 2022. The copyright holder for this preprint (which was not certified by peer review) is the author/funder, who has granted bioRxiv a license to display the preprint in perpetuity. It is made available under aCC-BY 4.0 International license.

a

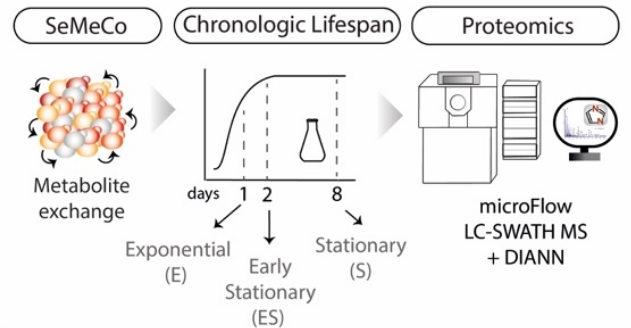

b

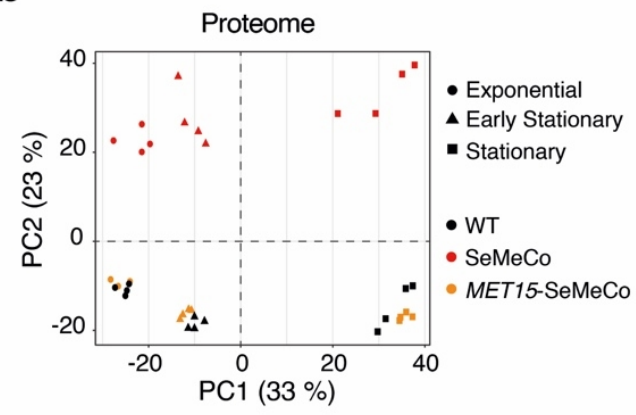

d

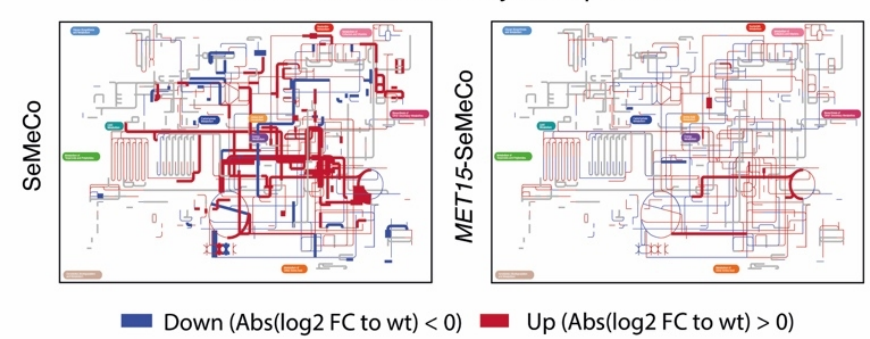

C
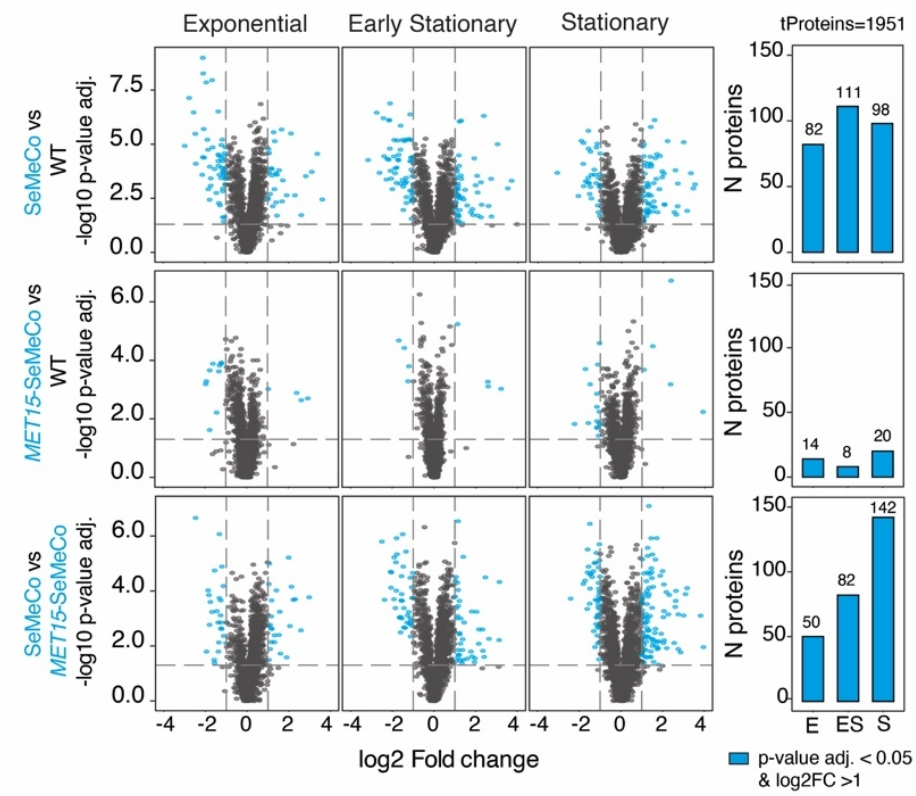

e

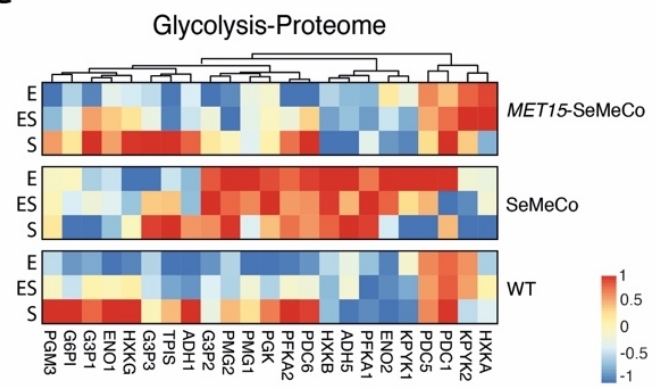

Figure 4. Widespread proteome and metabolome changes in yeast communities where MET15 and met15 $\Delta$ cells interact. a) Wild-type, SeMeCos, and MET15-SeMeCos (that do not segregate the MET15 marker) cells were collected at exponential (E), early stationary (ES) and stationary (S) growth phases. Proteomes were analysed using micro-flow LC-SWATH MS ${ }^{61}$ and DIA-NN ${ }^{62}$. Proteomics analysis was performed on four independent cultures (biological replicates) per yeast strain (total $n=12$ cultures). b) Principal component analysis (PCA) reveals that major proteome changes are driven by the 1212 transition from exponential to stationary phase (PC1, 33\%) and the segregation of the MET15 marker 1213 (PC2, 23\%). Individual data points represent biological replicates per strain. c) Volcano plots illustrate 1214 differential protein expression as log2 fold change (FC) to wild-type expression levels and -log10 adjusted 1215 p-value by $\mathrm{BH}$ method. Blue dots denote proteins above an absolute log2 FC of 1 (vertical dashed lines) and adjusted p-value $<0.05$ (horizontal dashed line) (left), with total number of proteins defined as per

1217 blue dots represented as bar graphs (right), per growth phase and pairwise comparison. Statistics by 1218 unpaired two-sided $t$-test and multiple testing correction using the $\mathrm{BH}$ method; adjusted $\mathrm{p}$-values are 
bioRxiv preprint doi: https://doi.org/10.1101/2022 03.07 483228- this version posted March 7, 2022. The copyright holder for this preprint (which was not certified by peer review) is the author/funder, who has granted bioRxiv a license to display the preprint in perpetuity. It is made available under aCC-BY 4.0 International license.

1219 listed in Supplementary File 13. d) Differential metabolic enzyme expression levels, from proteome

1220 analysis in a), mapped to the yeast metabolic network using IPATH3 ${ }^{100}$ in the early stationary phase

1221 (exponential and stationary phases are shown in Supplemental Fig. 13). Red and blue lines represent

1222 significantly (BH adjusted p-value <0.05) up- or down-regulated proteins in SeMeCos and MET15-

1223 SeMeCos when compared to wild-type; grey lines represent non-mapped/absent proteins in the

1224 measured proteomes. Thickness of the lines represent absolute log2 fold change $(\mathrm{Abs}(\log 2 \mathrm{FC}))$ changes

1225 (thickening $=$ increased $\mathrm{Abs}(\log 2 \mathrm{FC})$ ). e) Expression of enzymes belonging to the glycolysis pathway

1226 (columns), derived from the proteome analysis in a) and normalised to a -1 to 1 scale, per growth phase 
bioRxiv preprint doi: https://doi.org/10.1101/2022.03.07.483228; this version posted March 7, 2022. The copyright holder for this preprint (which was not certified by peer review) is the author/funder, who has granted bioRxiv a license to display the preprint in perpetuity. It is made available under aCC-BY 4.0 International license.

a
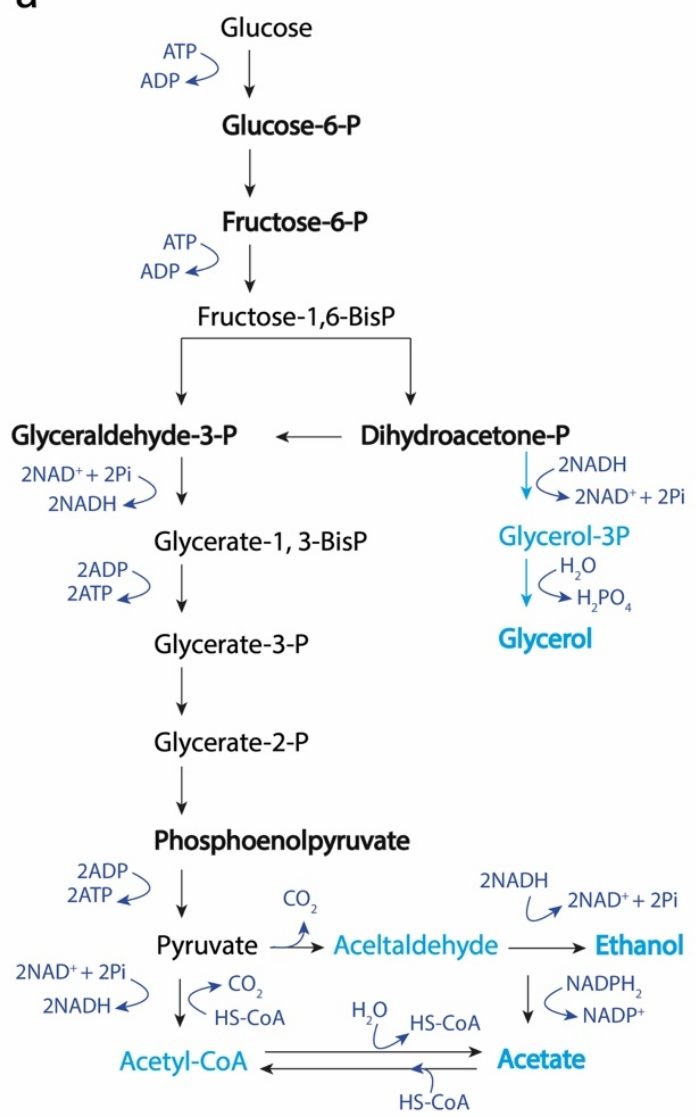

C

$\square$ WT

$\mathrm{SeMeCo}$

MET15-SeMeCo

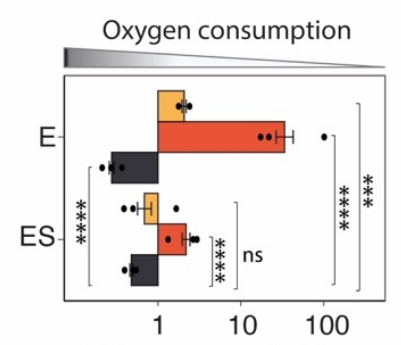

Fold change to wild-type d

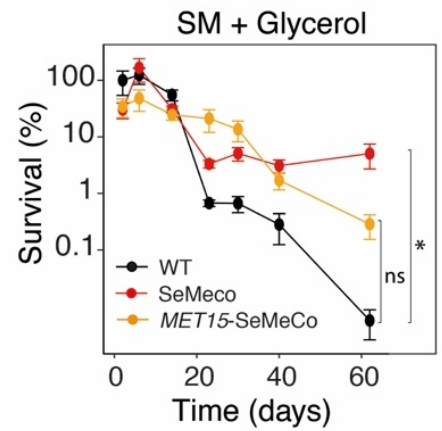

b

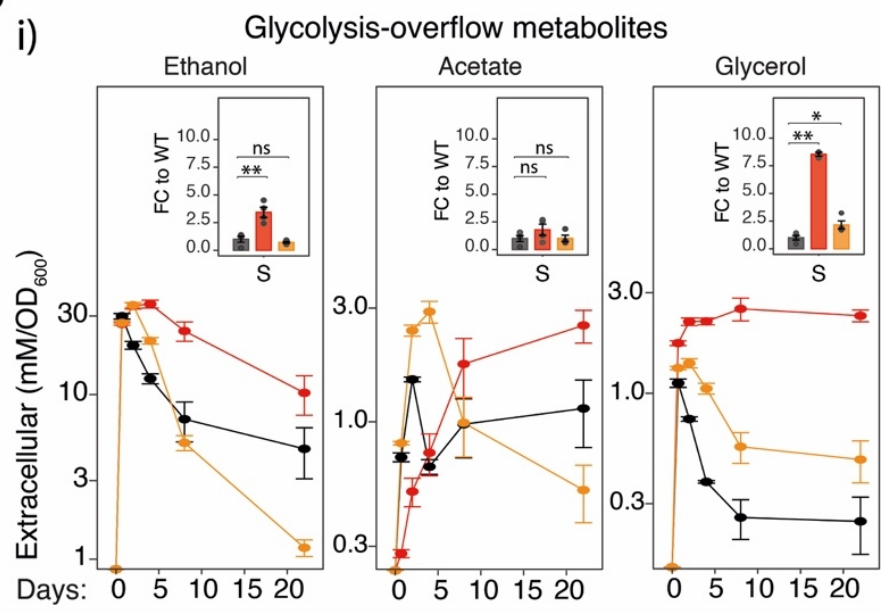

ii) Glycolysis-Intracellular metabolites

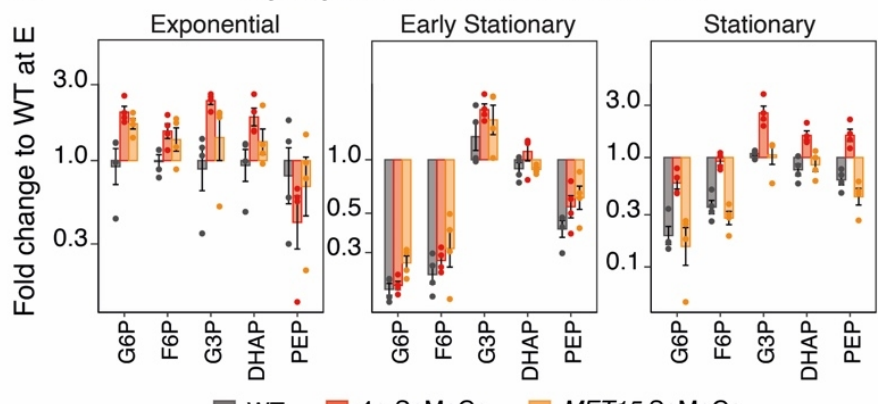

e

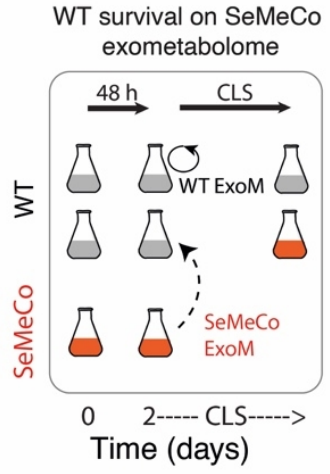

WT on WT exoM - - WT on SeMeCo exoM

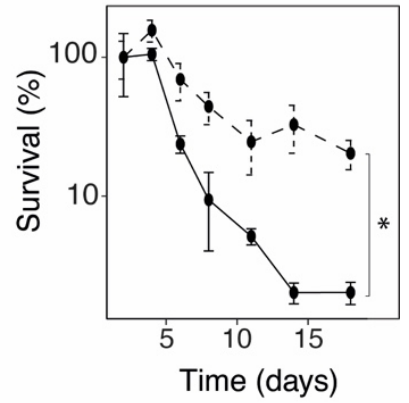

Figure 5. Lifespan extension in SeMeCos is promoted by a self-generated protective exometabolome. a) Fermentation (light blue) and glycolysis (black) reaction scheme and associated metabolites b) Quantification of i) the glycolytic overflow metabolites ethanol, acetate and glycerol in the exometabolome (by HPLC) and ii) intracellular glycolytic intermediates (by HPLC-MS/MS) of wild-type, SeMeCos, and MET15-SeMeCos that do not segregate the MET15 gene (top). Data are mean \pm SEM 
bioRxiv preprint doi: https://doi.org/10.1101/2022.03.07.483228; this version posted March 7, 2022. The copyright holder for this preprint (which was not certified by peer review) is the author/funder, who has granted bioRxiv a license to display the preprint in perpetuity. It is made available under aCC-BY 4.0 International license.

1234 metabolite levels ( $\mathrm{mM}$, normalised to biomass $\left(\mathrm{OD}_{600}\right)$ ); $\mathrm{n}=4$ independent cultures per strain (total $\mathrm{n}=12$

1235 cultures). Inlets in i) indicate fold change (FC) to mean wild type levels in the stationary phase (S, day 8);

1236 individual dots represent independent cultures. Statistics by unpaired two-sided $t$-test; ns= not statistically

1237 significant, $\mathrm{p}$-values ${ }^{*}<0.05,{ }^{* *}<0.005$; p-values are listed in Supplementary File 15. c) Oxygen $\left(\mathrm{O}_{2}\right)$

1238 consumption, as measured by $\mathrm{O}_{2}$ saturation in culture post 5 minutes of $\mathrm{O}_{2}$ levels recording (using a 1239 Hanna HI oxygen meter), in wild-type, SeMeCos, and MET15-SeMeCos, that do not segregate the 1240 MET15 gene, cultures in exponential (E) and early stationary (ES) growth phases. $\mathrm{O}_{2}$ levels were 1241 normalised to biomass, as measured by $\mathrm{OD}_{600}$, and to mean levels of wild-type in exponential phase. 1242 Data are mean \pm SEM fold change to wild-type mean levels in stationary phase, $n=3$ independent cultures 1243 per strain (total $n=9$ cultures). Statistics by unpaired two-sided Wilcoxon Rank Sum test; $p$-values are 1244 listed in Supplementary File 16. d) Chronologic lifespan assay, shown as survival measured by HTP1245 CFU normalised to biomass, of wild-type communities, SeMeCos, and MET15-SeMeCos, cultured on SM 1246 supplemented with glycerol. Data are mean \pm SEM survival (percentage fold change) compared to mean 1247 wild-type survival at the beginning of stationary phase ( $48 \mathrm{~h}$ culture); $\mathrm{n}=4$ independent cultures/ strain 1248 (total $n=12$ cultures). Statistics by unpaired two-sided Wilcoxon Rank Sum test; $p$-value at day 62 of 1249 culture for wt vs SeMeCos $=0.0285$ and wt vs MET15-SeMeCos $=0.1142$, p-values across CLS are 1250 listed in Supplementary File 17. e) Chronologic lifespan assay, shown as survival measured by HTP1251 CFU normalised to biomass, in wild-type cultures swapped to SeMeCos culture media (SeMeCo 1252 exometabolome (exoM)) or kept in their culture media (WT exoM) at the start of stationary phase (48h of 1253 growth). Data are mean \pm SEM survival (percentage fold change) compared to mean wild-type survival at 1254 the beginning of stationary phase (48h culture); $n=4$ independent cultures per exoM. Statistics by 1255 unpaired two-sided Wilcoxon Rank Sum test; $p$-value $=0.0286$ at day 18 of culture; $p$-values across CLS 1256 are listed in Supplementary File 18. 